\title{
Relevansi Konsepsi Rahmatan Lil Alamin dengan Keragaman Umat Beragama
}

\section{Solikhun Solikhun ${ }^{1 *}$}

1 IAIN Purwokerto, Indonesia; Solikhun220@gmail.com

* Correspondence

Received: 2021-02-06; Accepted: 2021-04-28; Published: 2021-04-30

\begin{abstract}
The impression of western world to the eastern has not shown a positive proportion. It always considers the latter as a minor. It is more so after the incident of WTC 9 September 2001. The eastern or as an assertive known as a terrorist, unhuman, and far from humane proportion. While in Islam itself, there is rahmatan li al-'alamin. These things make the researcher interested in examining deeper what it means to be a rahmatan li al-'alamin in Koran as a source of that word. Apart from the phrase rahmatan li al-'alamin, a rahmat word is not connected to the li al-'alamin word (universe) in the Koran. What also precisely is the difference between grace (rahmat) and rahmatan li al-'alamin. Indonesia is a plural nation. That is not only ethnic, language, and custom tradition, but also religion. How is the relationship between faith in diversity frame? Is there relevance of li al-'alamin in the diversity frame of religious people? Some questions need to search for answer in various reverence. The nation's founders have been proud not to obtrude by doing sharia for the adherents is a space for tolerance and religious people.
\end{abstract}

Keyword: religious pluralism, tolerance, sharia, terrorism, religious grace

Abstrak: Kesan Barat terhadap dunia Timur, belum menunjukkan nilai yang positif. Selalu dipandangnya minor. Terlebih setelah adanya peristiwa WTC 9 September 2001. Timur atau tegasnya adalah Islam dipandangnya sebagai Teroris tidak manusiawi dan jauh dari nilai-nilai kasih sayang. Sementara dalam ajaran Islam sendiri terdapat rahmatan li al-alamin. Hal inilah kiranya yang memotivasi penulis untuk mengkaji lebih dalam apa sebetulnya yang dimaksud rahmatan li al-'alamin di dalam Al-Qur'an, karena sumbernya ada dalam kitab tersebut. Selain dari kata rahmatan li al'alamin, di dalam Al-Qur'an juga terdapat kata rahmat yang tidak dihubungkan dengan kata li al'alamin (alam semesta). Apa juga sebetulnya perbedaan antara rahmat dan rahmatan li al-'alamin. Sementara itu, bangsa Indonesia adalah bangsa yang majemuk. Kemajemukan itu bukan saja terdapat dalam suku, bahasa, adat istiadat, tetapi juga agama. Bagaimanakah hubungan antar agama dalam bingkai kemajemukan? Adakah relevansi rahmatan li al-'alamin dalam bingkai kemajemukan umat beragama adalah sejumlah pertanyaan-pertanyaan yang perlu dicarikan jawaban dalam berbagai referensi. Para pendiri bangsa yang telah berbesar hati dengan tidak memaksakan kehendaknya dengan melaksanakan syariat bagi pemeluk-pemeluknya, adalah penyedia ruang bagi adanya toleransi antar umat beragama.

Kata Kunci: kemajemukan umat beragama, toleransi, syariat, terorisme, rahmat keagamaan

\section{Pendahuluan}

Berbagai kalangan, baik individu maupun kelompok dalam bentuk organisasi keagamaan menginginkan dirinya sebagai yang santun, yang ramah (Wibisono, 2020). Pembahasan mengenai rahmatan li al-alamin di dalam Al-Quran tidak lepas dari kajian terhadap surat Al-Anbiya' ayat 107 . M. Quraish Shihab dalam tafsir Al-Misbah menerangkan bahwa di dalam ayat 107 surat Al-Anbiya' tersebut terdapat 4 hal pokok, 1). Rasul atau utusan Allah, dalam hal ini adalah Nabi Muhammad Saw, 2). Yang mengutus beliau adalah Allah, 3). Yang di utus kepada mereka ('alamin), 4). Risalah yang kesemuanya mengisyaratkan sifat-sifatnya, yakni rahmat yang sifatnya sangat besar sebagaimana 
tersirat dalam ungkapannya yang umum atau nakiroh/indifinitif dalam kalimat (wa ma) belum lagi di tambah cakupannya yang luas meliputi waktu dan tempat. Surat ini juga membahas keistimewaan Nabi Muhammad Saw. Keistimewaan itu adalah kepribadian beliau yang merupakan rahmat, di samping ajaran yang disampaikannya (Shihab, 2002).

Di dalam kosa kata "arsalnaka" ayat 107 surat Al-Anbiya' juga menyiratkan adanya risalah. Risalah adalah ajaran-ajaran Allah yang disampaikan melalui perantaraan seseorang atau beberapa orang rasul untuk mengatur kehidupan manusia dalam hubungannya dengan Allah SWT., sesamanya dan lingkungannya. Meskipun manusia telah diberi hidayah oleh Tuhan berupa akal, akan tapi ia tidak bisa menentukan jalan hidupnya sendiri karena kemampuan akal manusia terbatas. Bila manusia dibiarkan mengatur hidupnya sendiri maka kehidupan ini akan berantakan karena antara satu dengan yang lain akan saling berbenturan, beda pendapat, menang sendiri mengalahkan orang lain. Karena keterbatasan kemampuan manusia itulah, Tuhan mengutus rasul-rasul-Nya untuk membawa risalahNya berupa peraturan-peraturan dengan ajaran-ajaran yang harus ditaati oleh setiap orang demi tumbuhnya perasaan hati yang aman dan tenteram sehingga dengan peraturan dan ajaran tersebut manusia dapat mengembangkan hasil di muka bumi berupa peradaban (Nasution, 2002).

Intisari dari Islam sebagaimana yang terkandung di dalam kata Islam itu sendiri yaitu: 1). Berserah diri, menundukkan diri, atau taat sepenuh hati, 2). Masuk ke dalam kata salam, yaitu selamat sejahtera damai, hubungan yang harmonis, atau keadaan tanpa noda dan cela. Dengan demikian intisari dari Islam adalah berserah diri atau taat sepenuh hati kepada kehendak Allah demi tercapainya kepribadian yang bersih dari cacat dan noda, hubungan yang harmonis dan damai sesama manusia, atau selamat sejahtera di dunia dan akhirat (Nasution, 2002).

Ke-rahmat-an Nabi Muhammad Saw, bukan saja karena kedatanganya membawa ajaran, tetapi sosok dan kepribadian beliau adalah rahmat yang di anugerahkan Allah Swt. Kepribadian tersebut dibentuk oleh Allah sehingga bukan hanya pengetahuan yang dilimpahkan kepada beliau melalui wahyu Al-Quran, tetepi kalbunya juga disinari wahyu ilahi bahkan totalitas wujud beliau merupakan rahmat bagi seluruh alam. Satu satunya Nabi yang dijuluki dengan rahmat adalah Nabi Muhammad S.A.W dan juga disifati dengan sifat Allah Ar-Rahim sebagaimana dalam kandungan surat At-Taubah: 128 Artinya: "Sungguh telah datang kepadamu seorang Rasul dari kaummu sendiri, berat terasa olehnya penderitaanmu, sangat menginginkan (keimanan dan keselamatan) bagimu, amat belas kasihan lagi Penyayang terhadap orang-orang mukmin."

Rasulullah SAW. adalah rahmat yang dihadiahkan Allah pada seluruh alam. Pembentukan kepribadian Nabi Muhammad Saw, berupa sikap, ucapan, perbuatan, etika dari beliau adalah rahmat yang bertujuan untuk mempersamakan totalitas beliau dengan ajaran yang sampaikan. Jika ajaran beliau adalah rahmat cocok antara risalah dan Rasul, karena Rasulullah penerjemah dari akhlak AlQuran sebagaimana sifat yang dilukiskan oleh Aisyah RA (Shihab, 2002).

Kata Al-Alamin seperti disampaikan Quraish Shihab dengan mengutip para pakar diartikan dengan keseluruhan jenis mahluk Allah yang hidup. Baik yang hidup sempurna maupun yang terbatas. Cakupanya meliputi alam manusia, alam malaikat, alam hewan dan tumbuh-tumbuhan semua itu memperoleh rahmat dengan kehadiran Nabi Muhammad SAW.,Dengan ajaran Islam yang penuh rahmat itu terpenuhilah hajat semua manusia dengan penuh ketenangan, ketenteraman, pengakuan atas wujud hak bakat dan fitrahnya sebagaimana pula hajat keluarga kecil dan besar menyangkut saling pengertian dan penghormatan. Tidak saja manusia yang mendapat rahmat Nabi Muhammad Saw, tetapi binatang dan tumbuh-tumbuhan pun mendapat rahmat tersebut. Rahmat itu antara lain seperti tidak membebani melebihi kemampuanya, juga mengasah pisau sebelum menyembelihnya (HR.Muslim). Beliau juga memperingatkan adanya seorang wanita yang masuk neraka sebab mengurung kucing hingga kucing tersebut tidak bisa mencari makan (HR. BukhariMuslim). Nabi juga melarang memetik bunga sebelum mekar, buah sebelum matang, karena tugas manusia adalah mengantar semua kepada tujuan penciptanya bunga agar mekar. Dari hikmah keindahan inilah dapat dinikmati oleh mata (Shihab, 2002).

Selanjutnya alam dalam pemahaman ulama, adalah mencakup apa saja selain Allah. Baik alam musyahadah yang berkaitan dengan hal yang dapat diamati oleh indera manusia, maupun alam ghaib 
yang tidak dapat diamati oleh indera mencakup apa yang dibumi dan apa yang dilangit atau mencakup malaikat, roh, jin setan, iblis, manusia, binatang, tumbuhan dan benda-benda mati. Oleh karena itu kata 'alam diungkapkan dengan mengambil bentuk jamak ('alamin). Tidak sedikit ayat-ayat Al-Quran yang memberikan informasi bahwa Tuhan yang menciptakan dan mengatur bumi dan langit (Nasution, 2002). Dialah yang mencipta bumi dan segala sesuatu ini. Jelaslah bahwa alam adalah ciptanya juga bahwa segala sesuatu ditetapkan ukuran dan pola mengikuti takdirnya atau menurut jumlahnya (hukum-hukum yang ditentukan Tuhan bagi alam) (Nasution, 2002).

Dalam ensiklopedi Indonesia dinyatakan bahwa rahmat dalam gereja katholik dimaknai dengan karunia supranatural. Yaitu merupakan pemberian cuma-cuma diberikan oleh Tuhan kepada makhluk yang berakal budi guna keselamatan rohaninya. Rahmat itu diberikan kepada manusia berkat Yesus. Meskipun dalam definisi itu disebutkan secara umum dan berkait dengan gereja katholik, sehingga yang menjadi wasilah adalah Yesus, namun demikian tetap saja dapat dipetik pengertian bahwa rahmat adalah pemberian Zat Yang Maha Kuasa yang diberikan secara cuma-cuma sebagai fadal (karunia) dariNya kepada manusia dan makhluk hidup pada umumnya dengan perantaraan NabiNya yang dalam paham Islam adalah Nabi Muhammad Saw (Nasution, 2002).

Risalah Nabi Muhammas Saw diturunkan kepada manusia saat mereka telah mengalami kedewasaan akal. Risalah yang terangkum di dalam Al-Quran itu sangat terbuka keberadaannya. Ia lentur dengan berbagai kondisi dan situasi. Ia mengandung pokok-pokok ajaran yang tidak berubahubah tetapi siap menerima kebutuhan hidup yang selalu berubah-ubah, yang diketahui oleh Zat Yang Maha Mengetahui dan Maha Teliti. Untuk mengkajinya secara mendalam manusia disilahkan melakukan ijtihad guna menyesuaikan pertumbuhan dan perkembangan dengan hukum yang tetap itu. Kedatangan Nabi Muhammad SAW., membawa syari' at sebagai rahmat karena keberadaanya yang elastis dan tidak beku. Hukum akan tumbuh kapan dan dimana pun juga, seiring dengan adanya illat atau sebab dari hukum tersebut (Hamka, 1982).

Rahmat yang tidak kalah penting dari risalah Nabi Muhammad Saw, adalah adanya kemerdekaan berfikir. Hal mana ketika seseorang melakukan ijtihad benar maupun salahnya tetap mendapatkan pahala. Jika benar mendapatkan dua pahala, dan jika salah mendapatkan satu pahala sebagai upah atas jerih payah yang dilakukan dalam berijtihad tersebut. Rahmat yang lain lagi adalah adanya motivasi seimbang dalam rangka mencapai kesempurnaan jasmani dan rohani. Tidak dibenarkan dalam Islam seseorang yang ingin mencapai kesempurnaan rohani dengan melakukan penistaan terhadap jasmani. Demikian juga sebaliknya tidak dibenarkan orang yang ingin mendapatkan kesempurnaan jasmani dengan tidak memperdulikan terhadap kesucian jiwa (Hamka, 1982).

Sesuatu yang dipikulkan kepada manusia adalah sesuatu yang tidak melebihi kesanggupannya. Sesuatu yang diperintahkan pun sesuatu yang membawa kemaslahatan bagi manusia. Sebagai rahmat dari risalah yang lainnya juga adalah terbebasnya dari kotak-kotak sekte kabilah. Dalam Islam tidak ada lagi yang lebih mulia dan terhormat disisi Allah S.W.T kecuali taqwanya. Pada awal-awal masuknya risalah, misi ini dipandang ganjil, karena yang ada saat itu adalah perbedaan ras. Kulit putih dipandang lebih terhormat daripada kulit hitam dan yang kaya dinilai lebih terhormat daripada yang miskin. Akan tetapi setelah datangnya risalah Nabi Muhammad taqwanyalah yang diandalkan dan terciptalah satu peradaban yang tinggi yang sangat memperhatikan terhadap hak-hak kemanusiaan. Ide persamaan hak dan kemerdekaan yang ditawarkan oleh Islam bukanlah isapan jempol belaka, tetapi betul-betul sebuah ajaran yang merahmati semesta alam. Tidak sebagaimana terjadi pada masa revolusi Perancis yang menawarkan kemerdekaan persamaan derajat, hanya bagi warga Perancis sendiri (Hamka, 1982).

Undang-undang yang digulirkan oleh Islam pun undang-undang atau aturan-aturan yang universal mengayomi seluruh semesta. Tidak sebagaimana aturan yang dibuat oleh tuan tanah yang hanya menguntungkan dirinya sendiri. Sebagai gambaran atas adilnya sebuah Pengadilan dalam Islam adalah seperti halnya riwayat Asy-Syu'bi tentang sahabat Ali yang kehilangan perisainya karena diambil oleh seorang Nasrani. Walaupun dalam persidangan Ali berkata bahwa pedang itu adalah milikku, akan tetapi karena Ia tidak memiliki saksi yang menguatkan, maka sayyidina Ali harus kalah dan kehilangan perisai. Namun setelah mengucap dua kalimah syahadat dan hendak berangkat 
bersama ke medan perang Siffin, Nasrani tersebut mengakui bahwa perisai itu adalah milik Ali. Meski demikian perisai tersebut pada akhirnya diberikan oleh Ali kepada Nasrani itu sebagai hadiah dia masuk Islam (Hamka, 1982).

Penggambaran di atas menyiratkan bahwa risalah Islam adalah sejuk, ramah dan dinamis. Namun keagungan Islam yang damai dan sejuk kemudian menjadi hal yang menakutkan seiring lahirnya pertikaian yang terjadi dalam Islam itu sendiri. Bermula dari kurun sahabat dan lebih khusus lagi pada masa khalifah Ali bin Abi Talib ketika bersengketa dengan Mu'awiyah bin Abi Sufyan. Jalan bijak yang diambil Ali melalui arbitrase untuk menyelesaikan konflik, tidak diterima oleh sekelompok orang yang kemudian menjadi golongan khawarij. Dilihat dari asalnya, kata khawarij berasal dari kata kharaja yang berarti keluar. Karena mereka keluar dari barisan Ali bin Abi Talib (Nasution, 2018). Nama lain dari khawarij adalah harura merupakan nama bagi satu desa yang terletak di Kufah, Irak. Dengan kekuatan anggota dua belas ribu orang, setelah memisahkan diri dari Ali memilih Abdullah bin Wahb Ar-Rasidi sebagai imam menggantikan Ali. Dalam pertempuran dengan Ali mereka mengalami kekalahan. Tetapi Abd Ar-Rahman bin Muljam berhasil membunuh Ali (Jabar, n.d.).

Meskipun mengalami kekalahan yang terus-menerus, tidak menjadikan mereka lelah dalam menyusun kekuatan dan melakukan perlawanan terhadap kekuasaan Islam resmi di zaman Bani Umayyah dan Dinasti Bani Abbas. Pemegang kekuasaan yang ada pada waktu itu dianggap sebagai menyeleweng dari umat Islam. Bagi mereka kepemimpinan Abu Bakar SHidiq dan Umar dapat diterima, akan tetapi kepemimpinan Ustman dianggap telah menyimpang khususnya pada tahun ke tujuh masa baktinya, demikian juga Ali setelah menerima adanya arbitrase. Ustman dan Ali menurut mereka telah menjadi kafir. Demikian juga Mu'awiyah, Amr bin As, Abu Musa Al-Asy'ari. Karena sebab anggapan telah kafir itulah maka mereka menganggap halal darahnya (Qattan, 2001).

Di Indonesia, pemberontakan DI/TII di Jawa Barat yang dipimpin oleh Sekarmaji Marijan Kartosuwiryo juga membuat resah masyarakat dan pemerintah dengan atas nama agama. Pemberontakan ini berkembang hingga Jawa Tengah, Aceh, Kalimantan Selatan, Sulawesi Selatan, berlangsung dari tahun 1949-1962 (Sugiyarto, 2015).

Tahun 2001 serangan berani mati terhadap menara kembar pusat perdagangan dunia (WTC) di New York, dan bangunan Pentagon di Airlington, Virginia dekat Washington DC, pada 11 September 2001, yang dalam penyelidikannya diarahkan kepada sebuah organisasi perlawanan (jihad), yang bernama Al-Qaidah, pimpinan Usama bin Laden juga menggertak dunia (Sugiyarto, 2015).

Setahun kemudian tanggal 12 Oktober 2002 peledakan bom di Pady's Pub dan Sari Club di Jalan Legian, Kuta Bali, dan ledakan di dekat Konsulat Amerika di Denpasar menambah tudingan bahwa Islam adalah menakutkan. Juga pengeboman yang terjadi di Jakarta dan beberapa tempat lainnya. Juga peledakan bom di Kedutaan Besar Philipina tanggal 1 Agustus 2000, bom yang dimulai malam jelang Natal, 24 Desember 2000, bom Bali 12 Oktober 2002, bom JW Marriot, 1 Agustus 2003, bom Kedutaan Besar Australia atau bom Kuningan, 9 September 2004. Bom Bali II tahun 2005 dan peledakan JW Marriot dan Hotel Ritz Carlton, 17 Juli 2009 terkait dengan organisasi bawah tanah yang gerakannya terasa hingga kemana-mana merupakan serentetan peristiwa yang mengundang perhatian dunia luas juga (Syukron, 2017).

The Wahid Institut mencatat selama kurun waktu tahun 2011 terjadi 92 kasus Pelanggaran Kebebasan Beragama Dan Berkeyakinan tahun 201062 kasus. Pelanggaran dan pembatasan aktifitas agama atau kegiatan ibadah 49 kasus, intimidasi dan ancaman kekerasan oleh aparat Negara 20 kasus, pembiaran kekerasan 11 kasus, kekerasan dan pemaksaan rumah ibadah masing-masing 9 kasus. Kriminalisasi atau viktimisasi keyakinan 4 kasus. Institusi Negara tercatat paling banyak melakukan pelanggaran kebebasan beragama. Polisi 32 kali, disusul Bupati, Walikota, atau pejabat Pemda 28 kali. Pelaku pelanggaran kebebasan beragama lainnya adalah tentara 16 kali, Satuan Pamong Praja 10 kali, pemerintah Provinsi 8 kali, Kantor Kementerian Agama dan KUA 8 kali (Sugiyarto, 2015).

Jawa Barat merupakan daerah dengan sebaran pelanggaran tertinggi yaitu 55 kasus. Banten 9 kasus, Aceh 5 kasus, Jawa Timur, Jawa Tengah dan Sulawesi Selatan masing-masing 4 kasus. Kategori intoleransi yang paling tinggi adalah intimidasi dan kekerasan atas nama agama 48 kasus. Tindakan intoleransi tertinggi adalah penyebaran kebencian terhadap kelompok lain 27 kasus, pembakaran dan 
perusakan properti 26 kasus, diskriminasi atas nama agama 26 kasus. Jawa Barat daerah intoleransi tertinggi 105 kasus, Jakarta 105 kasus, Riau 9 kasus (Sugiyarto, 2015).

Pada tahun 2011 ICRP mencatat bahwa aksi-aksi kekerasan dan diskriminasi cenderung meningkat paling brutal terhadap Jemaat Ahmadiyah di Cikeusik pada tanggal 6 Februari 2011 dengan memakan korban tiga orang meninggal. Kasus ini juga menyulut desakan pembubaran dan juga munculnya Keputusan Kepala Daerah yang melarang aktifitas Ahmadiyah. Survei yang dilakukan Lembaga Kajian Islam dan Perdamaian pada bulan Oktober 2010 hingga bulan Januari 2011 mendapatkan data adanya persoalan yang mendasar yaitu berkembangnya pemahaman radikal dan anti toleransi yang memasuki ruang pendidikan. Dari 100 SMP dan SMA umum di Jakarta dan sekitarnya dari 993 siswa yang disurvei atau 48,9\% menyatakan setuju atau sangat setuju terhadap aksi kekerasan atas nama agama dan moral. 51.1\% kurang setuju dan sangat tidak setuju (Sugiyarto, 2015).

Diantara 590 guru agama yang menjadi responden $28,2 \%$ setuju atau sangat setuju aksi kekerasan berbaju agama. Survei LSI dan Yayasan DENY JA menyebutkan bahwa tahun 2012, masyarakat kehilangan kepercayaan dan kepuasan terhadap lembaga Negara demikian rendah. Ketidakpuasan masyarakat terhadap lembaga Kepresidenan 62,7\%, terhadap Polisi 64,7 \% terhadap parpol 58,1\% disebabkan oleh karena kerja lambat, terkesan apatis, pembiaran pelbagai kasus pelanggaran HAM kebebasan beragama di Indonesia. Juga The Wahid Institute di tahun 2013 selama bulan Januari hingga bulan Desember tahun 2013 intoleransi 245 peristiwa 106/43\% melibatkan aktor Negara. 139/57\% aktor non Negara. Total tindakan kekerasan dan intoleransi $43 \%$ oleh aktor Negara 159/57\% oleh aktor non Negara (Sugiyarto, 2015).

Pada tahun 2012 hasil survey yang dilakukan oleh Yayasan DENNY JA dan LSI Community menunjukan trend intoleransi masyarakat Indonesia makin meningkat. Masyarakat semakin tidak nyaman akan adanya orang lain yang berbeda identitas (berbeda agama, dan berbeda aliran dalam satu agama) (Djelantik, 2010). Di tahun 2005 yang keberatan hidup berdampingan dengan beda agama 6,9\% tahun 2012 naik menjadi 15\%. Sedang yang keberatan hidup berdampingan dengan orang beda aliran agama (Syiah) 26,7 \% pada tahun 2005 meningkat menjadi 41, 8\% di tahun 2012 (Djelantik, 2010).

Publik yang keberatan untuk hidup berdampingan dengan yang berbeda identitas tersebut, mayoritas adalah mereka yang berpendidikan dan berpenghasilan rendah (SMA ke bawah) sekitar $67,8 \%$. Keberatan untuk bertetangga beda agama $61,2 \%$. Sedangkan mereka yang berpendidikan tinggi (SMA ke atas), 32,2\% tak nyaman bertetangga dengan yang beda agama, 38,8\% keberatan untuk bertetangga dengan orang Syi'ah. Masyarakat kita memiliki kebencian kepada Syi'ah sejak tahun 2005 hingga 2012 cenderung meningkat (Djelantik, 2010).

The Wahid Institue melaporkan tahun 2016 kaum muda terlibat dalam dukungan aktivitas kekerasan keagamaan (jihad) dan terorisme mencapai $76 \%$. Mendukung tindakan intoleransi beragama 46\%. Tahun 2017 Kerohanian Islam (rohis) Jabodetabek melakukan kajian jihad dalam makna perang $87 \%$. Temuan The Wahid Institute memberikan gambaran bahwa kaum muslimin muda telah memiliki pemikiran bahwa jika ada aksi kekerasan atas nama agama Islam dibenarkan. Fakta di atas juga menunjukan sikap toleransi dan kesadaran keberagamaan di Indonesia masih menjadi tantangan besar (Sugiyarto, 2015).

Data lain yang menunjukan kekerasan berlatar belakang agama adalah: Setara Institute (2010) bahwa sepanjang tahun 2010 terjadi 216 peristiwa pelanggaran kebebasan beragama/berkeyakinan yang mengandung 286 bentuk tindakan yang tersebar di 20 Provinsi. Dari 286, 103 tindakan dilakukan oleh Negara yang melibatkan para penyelenggara Negara sebagai aktor. Institusi Negara yang melakukan tindakan pelanggaran adalah: kepolisian dengan tindakan 56 kali. Selanjutnya Bupati/Walikota, Camat, Satpol PP, Pengadilan, Kementerian Agama, TNI, Menteri Agama, dan institusi lain. Setara Institute juga melakukan riset pada tanggal 20 Oktober sampai dengan 10 November 2010, terhadap 1.200 responden dengan sasaran warga Jakarta, Bogor, Depok, Tangerang dan Bekasi menunjukan adanya peningkatan trend anti toleran 49,5\% tidak menyetujui adanya rumah ibadah bagi yang berbeda agama. $45 \%$ menerima, dan lainnya tidak menjawab (Sugiyarto, 2015).

Beberapa persoalan isu antar agama menjadi isu penting untuk dibicarakan dalam hubungannya dengan beberapa perilaku dan tindakan kekerasan antar agama di Indonesia yang dilakukan dan 
diyakini oleh kaum muda muslim. Dalam hal menerima Pancasila sebagai dasar Negara Indonesia $56 \%$. Mendukung khilafah di Indonesia 86\%. Seperti dilaporkan The Wahid Institute 2017 dan Navara Foundation juga merilis $23,4 \%$ mahasiswa tidak setuju dengan Pancasila sebagai dasar Negara, tetapi khilafah Islamiyah. Pelajar juga 23,4\% mendukung khilafah Islamiyah bukan Pancasila. Kaum muda Islam tidak setuju dengan pendirian tempat ibadah berupa gereja $46 \%$. Ketika umat Kristen hendak mendirikan gereja, sebagian umat Islam marah dan menolaknya hingga ada yang membakarnya (Sugiyarto, 2015).

Persoalan lain yang serius juga masalah pindah agama. Soal pindah agama dianggap kafir dan murtad (bukan lagi beriman). Pemilihan agama dalam Islam sekalipun dipersilahkan oleh kitab suci tetapi tidak demikian dalam praktik. Pindah agama dilarang, tetapi kalau dari awal bukan Islam tidak dipersoalkan. Beberapa persoalan penyebab radikalisme dan terorisme kaum muda seperti: ekonomi, politik, mentalitas, agama dan kultural merupakan hal yang perlu diperhatikan. Sebab radikalisme dan terorisme berdasarkan argumen keagamaan sekalipun, tidak sesuai dengan ajaran keagamaan yang rahmatan li al-'alamin. Menurut Yeni Wahid, kesenjangan sosial dan ketidakpuasan sebuah kebijakan menimbulkan konflik agama dan sosial. Hal itu ditambah dengan adanya Undang-undang yang bernuansa intoleransi. Pada tahun 2016 terjadi 204 dengan 13 tindakan pelanggaran Kebebasan Beragama dan Berkeyakinan. Sementara tahun 2015, tercatat 190 peristiwa dengan 249 tindakan pelanggaran (Sugiyarto, 2015).

Selain itu juga adanya organisasi Internasional ISIS. Sebuah kelompok yang melakukan operasinya di Irak dan Suriah, namun pengaruhnya mendunia. Gerakan ini awalnya dipimpin oleh Abu > Bakar Al-Bag\}dadi yang dikenal sadis dan menghalalkan segala cara dalam mencapai tujuannya seperti: membunuh, membantai, menjarah, menteror terhadap mereka yang berbeda paham dan menghalangi serta menolak keberadaan ISIS. Gerakan ini memiliki ciri yang melekat antara lain: Pertama, berbendera hitam. Kedua, kelompok yang lemah. Ketiga, hati yang keras (arogan dan sadis). Keempat, mengaku mendirikan Daulah Islamiyah yang bertujuan mendirikan Negara Islam. Kelima, mengajak kepada Al-Quran. Keenam, nama-nama mereka menggunakan julukan atau alias. Ketujuh, nama keluarga mereka adalah nama daerah. Kedelapan, memelihara janggut hingga panjang (Sugiyarto, 2015).

Jika diperhatikan dengan seksama, maka kiranya dapat dikemukakan bahwa diantara sebab yang memungkinkan munculnya gerakan radikalisme dan terorisme adalah adanya pemahaman keagamaan yang keliru. Yaitu karena adanya keyakinan akan teks suci yang mengajarkan tentang terorisme dari kata jihad (Qodir, 2014). Dari sinilah penulis kemudian mempunyai sejumlah pertanyaan-pertanyaan diantaranya: mengapa kekerasan dan intoleransi terjadi dan cenderung meningkat? Apakah ada kekeliruan dalam beragama? Sementara di dalam sebuah hadis, Nabi menyatakan artinya: "mukmin sejati adalah mereka yang bisa memberikan keselamatan darah dan harta kepada orang lain." (HR. at-Tirmidzi dan an-Nasa'i). Hal ini menunjukan bahwa menjaga keselamatan orang lain merupakan hal yang utama.

Sebelum penulis melakukan kajian lebih jauh dan mendalam tentang term rahmatan li al-'alamin, terlebih dahulu penulis membaca beberapa tulisan yang berkait dengan tema rahmatan li al-'alamin. Diantara tulisan-tulisan tersebut adalah tulisan yang ditulis oleh Siswoyo Aris Munandar berjudul "Islam Rahmatan li al-Alamin Dalam Perspektif Nahdlatul 'Ulama" termuat dalam jurnal Pendidikan Islam ELTarbawi Sekolah Tinggi Agama Islam Sunan Pandanaran. Siswoyo Aris Munandar dalam tulisannya menyimpulkan:

a) Di tengah-tengah Al-Quran terdapat kata "walyatalattaf" yang biasanya dalam cetakan Indonesia berwarna merah memiliki makna lembut.

b) Islam sebagai agama dan Nabi Muhammad sebagai pembawanya sama-sama hadir untuk membawa kedamaian, kelembutan dan kebaikan tertinggi. Manusia yang beragama, tetapi tidak sampai pada tingkat kemanusiaan yang tinggi, disebut oleh Al-Quran sebagai pendusta agama sebagaimana tersirat dalam surat $\mathrm{Al}-\mathrm{Ma} a^{\prime} u n$ ayat 1-3. Kebaikan kemanusian tertinggi itu adalah keselarasan hubungan vertikal dan horizontal. 
c) KH. Hasyim Muzadi sebagai perwakilan Nahdlatul Ulama dalam hubungannya dengan konsep rahmatan li Al-Alamin menyatakan bahwa Pancasila bukanlah agama, tetapi tidak bertentangan dengan agama. Pancasila bukan jalan, tetapi titik temu antara banyak perbedaan jalan. Hanya Pancasilalah yang dapat menyatukan perbedaan agama, suku, budaya, dan bahasa. Pancasila adalah dasar Negara yang membedakan antara Negara agama dan Negara sekuler. Ia bukan agama, tetapi melindungi semua agama dan etnik sehingga Indonesia tidak sekuler. Visi rahmatan li al'alamin lebih kepada Islamic Society (masyarakat Islam) daripada Islamic state (Negara Islam) (Munandar, 2019). Tulisan Siswoyo Aris Munandar ini menggunakan pendekatan sosiologis.

Ismail Yahya dalam artikelnya yang berjudul "Islam Rahmatan Lil 'Alamin" mengawali pembahasannya dengan mengatakan bahwa Islam berasal dari kata salama atau salima yang berarti damai, keamanan, kenyamanan, dan perlindungan. Dengan mengutip Muhammad Tohir al-Qadri dalam fatwa tentang terorisme menyatakan bahwa Islam adalah pernyataan absolut tentang perdamaian. Sebagai agama, Islam adalah manifestasi dari damai itu sendiri. Dia mendorong manusia untuk menciptakan hidup proporsional, damai, penuh kebaikan, keseimbangan, toleransi, sabar dan menahan amarah. Secara normatif dan essensial pula, bahwa Islam merujuk pada pengertian damai, perlindungan, keamanan, dan kenyamanan, serta memastikan terwujudnya kedamaian dan keselamatan untuk seluruh umat manusia dan orang muslim tidak lain adalah mereka yang mewujudkan nilai-nilai luhur Islam itu (Yahya, 2019).

Istilah Rahmatan lil 'alamin menurutnya terdiri dari dua kata yaitu rahmat dan al-'alamin. Rahmat berarti kasih sayang dan Al-Alaminberarti seluruh alam. Gagasan Islam Rahmatan lil 'alamin menurutnya adalah konsep yang abstrak. Dengan membawakan pendapat Nur Syam Ismail Yahya mengatakan bahwa Islam hadir sebagai rahmat bagi seluruh alam, bukan saja khusus bagi manusia, akan tetapi juga bagi alam lainnya. Sehingga melalui Islam yang diselamatkan bukanlah hablun min Allah dan hablun min an-nas saja, tetapi juga hablun min al-'alam. Gagasan Islam Rahmatan lil 'alamin mengembangkan pola hubungan antar manusia yang pluralis, humanis, dialogis, toleran, serta mengembangkan pengelolaan dan pemanfaatan alam dengan rasa kasih sayang (Yahya, 2019). Tulisan Ismail Yahya ini juga menggunakan pendekatan Sosiologis.

Merupakan artikel lain yang juga bersinggungan dengan rahmatan lil 'alamin adalah tulisan Muhammad Arifin. Muhammad Arifin dalam artikel yang berjudul "Apa arti Islam Rahmatan Lil 'Alamin?" dengan mengutip pendapat Quraish Shihab menguraikan bahwa rahmatan lil 'alamin menyangkut empat hal yaitu: pertama, adalah Yang Mengutus yaitu Allah SWT. Allah SWT menyatakan dirinya sebagai Ar-Rahman dan Ar-rahim. Kedua kata tersebut terbentuk dari kata dasar rahima yang berarti mengasihi, merahmati. Ar-Rahman merahmati semua makhluk tanpa adanya pengecualian. Ar-Rahim kasih sayangnya hanyalah akan diberikan kepada orang-orang yang beriman dan beramal salih. Kasih sayangnya yang tidak terbatas berupa surga hanya akan diberikan kepada mereka yang beriman. Rahmat dan kasih sayang Allah SWT mengalahkan segalanya. Meskipun Allah adalah al-Muntaqim yakni Yang Maha Pemberi sanksi akan tetapi rahmat-Nya lebih dominan. Meskipun pemberi sanksi, akan tetapi Dia adalah zat tetap penerima taubat dari orang yang maksiat sekalipun (Arifin, 2020).

Sebelum penulis menulisnya panjang lebar, penulis terlebih dahulu membaca para penulis pendahulu. Dengan menggunakan tiga pendekatan KH. Hasyim Muzadi mengampanyekan gagasan Islam Rahmatan lil 'alamin. Ketiga pendekatan itu adalah pendekatan dakwah, pendekatan hukum, dan pendekatan politik. Ketiganya dapat membawa Islam dengan rahmat, damai dan lemah lembut. Di negara-negara multi agama dan multi etnik, multi budaya itulah Islam telah teruji (Arifin, 2020). Tulisan ini juga menggunakan pendekatan sosiologis.

Di samping tulisan-tulisan yang jelas-jelas dalam judul dan uraiannya berkisar rahmatan lil 'alamin, terdapat juga tulisan-tulisan lain yang secara mafhum mukhalafah dapat dipahami adanya semangat rahmatan lil 'alamin. Tulisan-tulisan tersebut antara lain adalah tulisan Hasbiyallah dan kawan-kawan yang menulis artikel dengan judul "Deradikalisasi Islam Indonesia (Studi Pemikiran Islam Nahdlatul Ulama)". Tulisan ini merupakan laporan hasil penelitian kelompok. Penelitian ini dilakukan oleh Pusat Penelitian dan Penerbitan Lembaga Penelitian dan Pengabdian Kepada Masyarakat Universitas Islam 
Negeri Sunan Gunung Djati Bandung tahun 2016. Tulisan tersebut menyimpulkan: a). Bahwa Nahdlatul Ulama dalam mewujudkan cita-citanya melalui serangkaian ikhtiyar yang didasarkan pada faham keagamaan yang khas Nahdlatul Ulama yaitu: (1). Tawasut dan i'tidal yaitu bersikap tengahtengah dan tidak berat sebelah. (2). Tasamuh, yaitu toleran terhadap pandangan yang berbeda. (3). Tawazun, yaitu seimbang dalam berhidmat dan (4). Amar makruf nahi munkar, yaitu mendorong berbuat baik dan mencegah kemungkaran. b). Selain itu, dasar beragama Nahdlatul ‘Ulama juga berorientasi pada kemaslahatan. Beberapa dasar profetis moderasi Nahdlatul ‘Ulama adalah: (1). Memilih jalan damai. (2). Keragaman adalah fitrah manusia. (3). Jaminan keselamatan bagi orang-orang yang beriman kepada Allah dan hari Akhir. (4). Beragam Nabi, tetapi tetap satu umat. (5). Tidak ada paksaan dalam agama. (6). Beragama dengan kasih sayang. c). Upaya Nahdlatul Ulama dalam deradikalisasi Islam Indonesia dengan menggunakan dua pendekatan yaitu struktural dan kultural. Upaya struktural dilakukan dengan memberdayakan lembaga-lembaga dan badan-badan otonom yang ada sesuai tugas dan fungsinya. Sementara upaya kultural dilakukan oleh warga Nahdlatul 'Ulama dalam berbagai celah untuk meredam merebaknya faham dan gerakan radikal (Sulhan, 2018). Tulisan yang ditulis oleh Hasbiyallah dan kawan-kawan ini sebagaimana judul di atas, adalah menggunakan pendekatan sosiologi.

Selain tulisan di atas juga karya Nur Kafid dalam redaksi "masyarakat" merupakan artikel jurnal yang dipublikasikan oleh Lab Sosio Pusat Kajian Sosiologi Universitas Indonesia yang berjudul dari "Islamisme ke Premanisme" Pergeseran Orientasi Gerakan Kelompok Radikal di Era Desentralisasi Demokrasi. Dalam tulisannya Nur Kafid menyimpulkan: a). Perlunya memahami pergeseran orientasi gerakan kelompok keagamaan Islam beraliran radikal di era desentralisasi demokrasi, dari basis isu Islamisme (penegakan syariat Islam) ke arah premanisme (penguasan sumber daya ekonomi). b). Meskipun tindakan yang dilakukan itu bertentangan dengan hukum karena menggunakan cara-cara kekerasan, tetapi tidak jarang gerakan mereka justeru dianggap sebagai pelindung bagi masyarakat yang lain. c). Afiliasi politik kelompok keagamaan Islam radikal pada masa sebelumnya dan reformasi, lebih dominan ke partai politik (berbasis massa) Islam, terutama partai-partai yang menyuarakan penegakan syariat Islam. Pada era desentralisasi demokrasi ini afiliasi mereka mencair. Dari kalangan bisnis lebih berorientasi kepada penyelamatan bisnisnya tanpa memandang dasar partai (Kafid, 2016). Tulisan Nur Kafid ini mengamati pergeseran pergerakan aliran radikal ke premanisme dengan pendekatan sosiologi.

Busman Edyar menulis artikel dengan judul "Religious Radicalism, Jihad and Terrorism". Dalam tulisannya Busman menerangkan bahwa radikalisme berdasar agama bukan saja terjadi di Islam, tetapi di seluruh agama. Kristen, Hindu, Budha, Tao, dan Shinto semuanya terdapat radikalisme. Seperti terjadi di India dilatari oleh agama Hindu juga di Irlandia oleh agama Katolik. Di Indonesia kata Busmar dengan mengutip Ahmad Syafi'i Mufid radikalisme dapat dicirikan dengan hal-hal sebagai berikut: 1). Anggapan bahwa Pemerintahan yang ada adalah merupakan Thagut. 2). Menolak menyanyikan lagu Indonesia Raya. 3). Memiliki hubungan emosional yang kental dengan sesama anggota. 4). Kaderisasinya bersifat indifidu. 5). Ada iuran diantara mereka. 6). Dalam berpakaian cingkang bagi laki-laki, dan cadar bagi perempuan. 7). Menganggap muslim lain selain anggota mereka masih kafir sebelum hijrah seperti mereka. 8). Memiliki teks khusus bagi kalangan mereka yang beda dengan kelompok lain (Edyar, 2017). Tulisan Busman Edyar berusaha memahami radikalisme yang terdapat di dalam agama-agama di dunia dengan pendekatan sejarah.

Artikel Nurul Solihin berjudul "Understanding the Radicalism Movement In Indonesia: A Conflict Approach to the Rise of Terrorism" berusaha menguraikan bahwa terorisme yang terjadi di Indonesia dilatari antara lain oleh adanya eksploitasi, diskriminasi, dan masalah-masalah ekonomi. Ia lebih banyak menyoroti aktor-aktor di balik kerusuhan-kerusuhan yang terjadi. Mengingat posisi aktor adalah sangat penting dalam sebuah peristiwa (Solihin, 2017). Tulisan Nurul Solihin ini menelisik akar terorisme di Indonesia, dengan pendekatan sosiologi juga.

Muhammad Nasir menulis artikel dengan judul "The Historical Background of The Ideology of Terrorism in Indonesia After September 11, 2001". Ia menyatakan bahwa beberapa yang melatarbelakangi adanya tindak terorisme di Indonesia adalah: 1). Sosio politik konflik di Indonesia. Yaitu adanya 
konflik yang semula di Aceh memicu adanya solidaritas dari tempat lain demikian juga di Ambon dan Poso. Faktor ekonomi disebut-sebut juga turut serta memengaruhi lahirnya tindak terorisme. 2). Perang dunia. Satu hentakan yang luar biasa adalah terjadinya insiden 11 September 2001 yang merupakan langkah awal bermulanya terorisme di Indonesia. 3). Adanya Konspirasi. Teori konspirasi berusaha mengungkap misteri siapa di balik dalang dari pengeboman yang terjadi di Indonesia. 4). Jihad yang mendunia yang menjebol sekat dinding-dinding Negara tertentu adalah serentetan sejarah lahirnya aksi teror (Nasir, 2016). Tulisan Muhamad Nasir di atas juga menyoroti terorisme di Indonesia dengan pendekatan sejarah.

Artikel lain yang berjudul "Islamic Religious Learning In Providing Understanding Of Radical Hazard Based On Affection Approach" menambah referensi penulisan disertasi ini. Artikel yang di tulis oleh Kusen, menguraikan arti penting sistem pendidikan nasional tak terkecuali pendidikan Islam dan pendidikan agama termasuk institusi-institusi pendidikan agama. Baik pendidikan agama maupun institusi pendidikannya memiliki arti penting dalam menghadang terorisme di Indonesia. Oleh karena itu pemahaman atas radikalisme dan terorisme hendaklah dipahami oleh seluruh pemangku kepentingan pendidikan. Apalagi melihat bahwa termasuk yang menjadi sasaran rekrutmen agen radikalisme dan terorisme selanjutnya adalah siswa. Pendidikan agama menjadi benteng bagi merebaknya paham radikal dan munculnya benih-benih terorisme (Kusen, 2017). Tulisan Kusen ini juga berusaha mengurai akar radikalisme dan penyebarannya melalui pendekatan filsafat pendidikan.

Dengan beberapa uraian di atas jelaslah posisi penulis yang akan menelusuri rahmatan li Al-Alamin dari sisi tafsir Al-Quran secara tematik dikaitkan dengan keragaman umat beragama di Indonesia, yang tentu berbeda dengan tulisan-tulisan sebelumnya sebagaimana penulis paparkan.

\section{Metode Penelitian}

Artikel ini adalah membahas tentang rahmatan lil alamin Sehingga, sebagaimana yang berkembang dalam kajian tafsir, kajian tersebut termasuk kategori tafsir tematik. Dengan demikian kerangka teori atau landasan teori yang penulis gunakan dalam menyelesaikan tulisan ini juga tulisan-tulisan atau teori-teori yang berkait dengan tafsir tematik (Albar et al., 2020).

Pada tahun 1977 Abdul Hay Al-Farmawy guru besar fakultas ushuluddin Al-Azhar sebagaimana di ulas Quraish Shihab dalam buku membumikan al-Qur'an, menulis buku dengan judul Al-Bidayah fi Al-Tafsir Al-Mawdu'iy. Dalam buku tersebut dikemukakan bahwa kajian tafsir tematik dapat dilakukan dengan menggunakan langkah-langkah sebagai berikut: 1) Menetapkan masalah yang hendak dibahas, 2) Menghimpun ayat-ayat yang berkaitan dengan masalah tersebut, 3) Menyusun ayat sesuai dengan masa turunnya disertai dengan pengetahuan tentang asbab al-nuzulnya, 4) Memahami korelasi korelasi ayat-ayat tersebut dalam surahnya masing-masing, 5) Menyusun pembahasan dalam kerangka yang sempurna, 6) Melengkapi pembahasan dengan hadis-hadis yang relevan dengan pokok bahasan, 7) Mempelajari ayat-ayat tersebut secara keseluruhan dengan jalan menghimpun ayatayatnya yang mempunyai pengertian yang sama atau mengkompromikan antara yang umum ('am) dari yang khusus (khas), yang mutlak dari yang terikat (muqayyad) atau yang lahirnya bertentangan, sehingga kesemuanya bertemu dalam satu muara (Shihab, 2007). Di samping atikel ini secara metodologi merupakan kajian tafsir tematik, juga mengangkat sebuah tema risalah maka penulis juga membawakan tulisan-tulisan yang erat hubungannya dengan tema risalah.

\section{Hasil Penelitian}

\section{Sketsa Lafziyyah Rahmatan Li Al-'Alamin}

Perbincangan mengenai rahmatan li al-'alamin, bukanlah kata yang berdiri sendiri, akan tetapi tidak lepas dari kata sebelumnya yang terdapat dalam ayat yang sama yaitu surat Al-Anbiya' ayat 107 artinya: "tidak aku utus kamu kecuali untuk merahmati seluruh alam." Sebagai utusan, Rasulullah SAW diberi kitab suci sebagai rujukan dalam penyebaran risalahnya yaitu Al-Quran. Ketika menelaah AlQuran, maka bukan semata-mata tulisannya saja yang dimaksudkan. Akan tetapi seluruh isi dari 
kandungan Al-Quran tersebut. Seperti diketahui bahwa Al-Quran ini diturunkan adalah menjadi petunjuk dan juga bebungah bagi orang-orang yang beriman (R. I. Departemen Agama, 2005).

Masa-masa sebelum turunnya Al-Quran adalah masa-masa kelam. Hal mana pertumpahan darah dari tindasan orang-orang yang kuat terhadap yang lemah, pelecehan seksual terhadap perempuan, perdagangan yang zalim, riba dan kezaliman lainnya mewarnai kehidupan manusia kala itu (Syarqowi, 2003).

Syaikh An-Nadwi sebagaimana dikutip Abuddin Nata, menggambarkan masa jahiliyah itu sebagaimana bumi yang baru saja tertimpa gempa, ditambah dilanda tsunami. Sehingga banyak terdapat rumah-rumah roboh, gedung-gedung miring, dan harta benda berserakan tidak karuan, jasad manusia bergelimpangan. Al-Quran menyatakan bahwa kehidupan manusia saat itu sebagai rusak (fasad), kesesatan yang nyata (dalalin mubin), kegelapan (zulumat), permusuhan ('adawah), berada dalam tebing jurang neraka ('ala syafahufratin min an-nar). Keadaan manusia benar-benar chaos. Penyembahan mereka kepada benda yang secara akidah tidak dapat memberi apa-apa, baik material maupun sosial. Mereka hidup terkotak-kotak oleh adanya kabilah-kabilah, suku-suku yang diskriminatif. Kehidupan mereka diliputi dunia hedonistik, kapitalistik, dan kekuasaan mereka berada ditangan orang-orang kaya yang zalim (Nata, 2016).

Situasi yang demikian carut-marutlah yang akan diatasi oleh Allah SWT dengan pengutusan hamba-Nya yang dipilih melalui surat Al-Anbiya' ayat 107 sebagaimana tersebut di atas. Jika melihat dari terjemah ayat di atas "Dan Tiadalah Kami mengutus kamu, melainkan untuk (menjadi) rahmat bagi semesta alam", maka (wa) adalah adawat ataf bermakna "dan" (ma) adalah nafi berarti tidak dan arsalnaka adalah bentuk pertama yang maknanya telah lampau, berarti mengutus, dan (na) adalah damir muttasil dengan mu'azam nafsah (Kami) maksudnya adalah Allah sebagai zat yang mengutus, dan (Ka) adalah d\}amir munfasil berarti kamu (Muhammad SAW). Illa adalah istisna berarti kecuali dan rahmatan (maf'ul li ajlih) berarti menjadi rahmat. Li Al- 'Alamin adalah jar dan majrur pada kata jamak 'alam yang berarti semesta alam.

Dari terjemah perkata terhadap ayat di atas dapat dipahami bahwa ayat tersebut mengandung pertama adalah adanya risalah (al-Bajurî, 2007). Hal ini lahir dari kata arsalna. Kedua adalah adanya Allah yang mengutus adanya risalah tersebut, dan ketiga adalah adanya aktor yang mengusung risalah tersebut yakni Nabi Muhammad SAW. keempat adalah baik Nabi Muhammad maupun risalahnya menjadi rahmat. Kelima adalah alam semesta yang menjadi objek bagi tersemainya rahmat Allah tersebut. Meskipun ayat di atas dimulai dari kata arsalnaka yang berarti risalah, tetapi karena luasnya uraian risalah tersebut, maka pembahasannya akan didiskusikan setelah uraian mengenai diri Rasulullah sebagai aktor dari pembawa risalah. Rasulullah SAW. kedudukannya menjadi rahmat dapat dilihat dengan faktor-faktor di bawah ini.

Pertama, diri Rasulullah Muhammad SAW, sebagai aktor pengusung risalah hal mana sebelum isra'mi'raj tersebut terjadi, Muhammad SAW dioperasi tubuhnya dan dimasuki hikmah ke dalamnya, juga karena merupakan didikan dari Allah SWT (Ad-Dardiri, n.d.). Dari sinilah mengapa apa yang keluar dari mulutnya tidak lagi bias dengan hawa nafsunya tetapi selalu sejalan dengan wahyu. Surat An-Najm melegalisasi adanya kejernihan ucapan Rasul tersebut dalam ayat 1 sampai 4. 1) Demi bintang ketika terbenam. 2) Kawanmu (Muhammad) tidak sesat dan tidak pula keliru. 3) Dan Tiadalah yang diucapkannya itu (Al-Quran) menurut kemauan hawa nafsunya. 4) Ucapannya itu tiada lain hanyalah wahyu yang diwahyukan (kepadanya) (Majah, 1952; Rida, n.d.). Keadaan Rasulullah SAW sebagaimana tersebut di atas, menurut Abuddin Nata karena di dalam diri Rasulullah terdapat hal-hal sebagai berikut:

Pertama, unsur rasionalitas. Yaitu bahwa segala yang dilakukan oleh Rasulullah didasari oleh usaha yang keras, bukan semata-mata karena sudah menjadi Rasul dan dengan Pencipta kemudian hidup santai tanpa usaha dan do'a. Semua kesuksesan dari Rasulullah adalah karena kerja kerasnya yang dilakukannya sesuai aturan dan sunnatullah yang ada. Sebagaimana perang-perang yang dilakukan Rasulullah yang diikuti sahabatnya dengan tulus ikhlas mereka memperoleh kemenangan. Namun yang tidak mematuhi aturan Rasulullah terjadilah kekalahan sebagaimana terjadi dalam perang Uhud. Contoh lain dari unsur rasionalitas ini adalah mukjizat yang diberikan kepada 
Rasulullah yang berupa Al-Quran yang isi kandungannya demikian luas dan diyakini kebenarannya sekaligus dapat dipraktekkan dalam kehidupan masyarakat sehingga akan membawa keberkahan dan rahmat bagi seluruh alam (Yahya, 2019).

Kedua, unsur kecerdasan. Yaitu bahwa ketauladanan Nabi Muhammad SAW yang dapat membawa rahmat bagi yang mengikutinya adalah adanya unsur kecerdasan. Yakni sutu kemampuan intelegensia dan intelektual dalam ketepatan menganalisa dan mengambil keputusan yang tepat dan akurat yang terkadang tidak bisa dilakukan oleh orang lain. Sebagai contoh adalah peristiwa yang terjadi dalam perjanjian Hudaibiyah hal mana dalam perjanjian tersebut merugikan umat Islam yaitu dikembalikan, akan tetapi jika yang tertangkap adalah orang kafir Quraisy agar dikembalikan. Kebijakan ini oleh para sahabat dinilai lemah dan kurang cerdas. Namun Abu Bakar Siddiq mendorong sahabat lainnya agar mengikuti Rasulullah. Benar ketika perang Khaibar, yang jumlah kaum kafir Quraisy ribuan dapat dikalahkan oleh umat Islam. Hal inilah yang kemudian menggetarkan hati musuh hinga terjadinya fathu makkah. Di sini tampak dengan jelas akan kecerdasan Rasulullah dan kecerdasan inilah hakikatnya yang membawa rahmat bagi umat Islam (Yahya, 2019).

Ketiga, keseimbangan antara hati dan pikiran (heart and head) dan kemampuan teknis (hand). Hal ini dilakukan dalam setiap pengambilan keputusan. Segala apa yang hendak diekskusi sebagai sebuah perbuatan telah terlebih dahulu dikoordinasikan dengan akal pikiran, dipertimbangkan dahulu oleh hati nurani. Jika sudah cocok keputusan itu diambil. Inilah yang dilakukan oleh Rasulullah Muhammad SAW, sehingga apa yang dikeluarkannya selalu membawa rahmat bagi semesta alam (Yahya, 2019).

Keempat, komprehensif, yaitu bahwa ajaran yang dibawa oleh Rasulullah Muhammad SAW menyentuh semua aspek kehidupan sebagaimana dirumuskan oleh Asy-Syatibi dalam al-muwaqat dengan istilah maqasid asy-syar'iyah bahwa tujuan agama adalah mencakup memelihara jiwa (hifz annafs), memelihara agama (hifz ad-din), memelihara akal (hifz al-aql), memelihara harta (hifz al-mal), dan memelihara keturunan (hifz an-nasl) (Nata, 2016). Mengenai uraian panjang lebar tentang hal ini akan di bahas dalam risalah Islam.

\section{Ikhtisar Risalah Berbasis Rahmatan Li Al-'Alamin.}

Konsep Rahmatan li Al-Alamin dalam Al-Quran pada dasarnya merupakan konsep yang abstrak. Namun demikian bukan berarti bahwa konsep tersebut tidak dapat dipelajari. Para ulama telah berusaha mengakajinya untuk dapat mengupas apa itu risalah rahmatan li al-'alamin, salah satunya adalah Asy-Syatibi.

Asy-Syatibi menyatakan bahwa risalah Islam rahmatan li Al-Alamin jika diperas, maka akan lahir ringkasan bahwa risalah rahmatan li Al-Alamin hakikatnya adalah akan melindungi hak-hak dasar yang dibutuhkan manusia. Hak-hak dasar tersebut adalah sebagai berikut (AL-GHAZALI, n.d.):

1) Hak Hidup.

Islam menjamin hak kelangsungan hidup (hifz an-nafs). Islam sangat menghormati harkat dan martabat manusia, dan melarang siapa pun merendahkan harkat dan martabat tersebut. Dalam penerapan hukum Islam terdapat kepentingan terkait kehidupan orang banyak yang harus dijamin. Sebagaimana dinyatakan di dalam Al-Quran surat Al-An'a>m ayat 151 artinya:

"Katakanlah marilah kubacakan apa yang diharamkan atas kamu oleh Tuhanmu yaitu: janganlah kamu mempersekutukan sesuatu dengan Dia, berbuat baiklah terhadap kedua orang ibu bapa, dan janganlah kamu membunuh anak-anak kamu karena takut kemiskinan, Kami akan memberi rezeki kepadamu dan kepada mereka, dan janganlah kamu mendekati perbuatan-perbuatan yang keji, baik yang nampak di antaranya maupun yang tersembunyi, dan janganlah kamu membunuh jiwa yang diharamkan Allah (membunuhnya) melainkan dengan sesuatu (sebab) yang benar. Demikian itu yang diperintahkan kepadamu supaya kamu memahami(nya)".

Juga surat Al-Baqarah 179: "Dan dalam qisas itu ada (jaminan kelangsungan) hidup bagimu, Hai orangorang yang berakal, supaya kamu bertakwa." Hukum qisas menurut ayat ini adalah dalam rangka memberikan efek jera kepada masyarakat. Menghukum satu orang berarti menghidupkan seribu orang. Namun demikian tidak berarti tanpa ada peluang negosiasi dan pemaafan. Hukuman mati 
dapat dibatalkan jika keluarga korban memaafkan. Namun diganti dengan diyat (ganti rugi). Pelaku kejahatan pembunuhan begitu mengetahui sanksi hukuman pasti tidak akan melangsungkan niatnya untuk membunuh.

Manusia dalam hidupnya memiliki tiga fungsi yaitu sebagai makhluk Tuhan, makhluk indifidu dan makhluk sosial budaya. Ketiga fungsi itu terjalin sangat erat satu dengan lainnya. Kepada Tuhan memiliki kewajiban untuk menyembah kepada-Nya. Sebagai indifidu harus dapat memenuhi segala kebutuhan hidupnya. Sebagai makhluk sosial harus hidup berdampingan degan orang lain dalam kehidupan yang selaras dan saling bantu membantu dan tolong-menolong. Sebagai makhluk sosial inilah kemudian melahirkan kebudayaan (Setiadi, 2017).

2) Hak memelihara akal untuk berpikir dan berekspresi

Risalah Islam menjamin hak kebebasan beropini dan berekspresi (hifz al-aql). Dalam risalah Islam, berpikir adalah merupakan kewajiban. Risalah Islam tidak pernah membelenggu gerak pikiran umatnya untuk menggapai hakikat sebagai jembatan menghantar kepada keyakinan. Rasul bersabda: berpikirlah dalam makhluk Allah dan jangan berpikir tentang zat Allah (R. I. Departemen Agama, 2005).

Risalah Islam menghargai manusia akan kebebasan berfikir dan berekspresi. Orang yang berilmu lebih tinggi daripada orang lain (Ibnu Ismail, n.d.). Kebebasan berpikir usaha memperoleh ilmu tingkat tinggi yang bisa dimanfaatkan untuk menyiarkan kebajikan, bukan kezaliman. Sikap Rasulullah dalam mengapresiasi pikiran sahabat dalam strategi perang uhud merupakan contoh dari keluasan wawasan dan rahmat yang diberikan Rasul kepada sahabatnya (Rida, n.d.).

Demikian penting kedudukan akal dalam kehidupan, maka dilarang untuk dirusak. Salah satu yang bisa merusak pikiran adalah zat adiktif atau khamr (Rida, n.d.). Oleh karena itu Allah menegaskan dalam surat Al-Baqarah ayat 219 sebagai berikut artinya: "Mereka bertanya kepadamu tentang khamar dan judi. Katakanlah: "Pada keduanya terdapat dosa yang besar dan beberapa manfaat bagi manusia, tetapi dosa keduanya lebih besar dari manfaatnya", dan mereka bertanya kepadamu apa yang mereka nafkahkan. Katakanlah: "yang lebih dari keperluan." Demikianlah Allah menerangkan ayat-ayat-Nya kepadamu supaya kamu berfikir."

Ustman bin Affan berkata jauhilah olehmu minuman keras (khamr). Karena zaman sebelum umat Islam ini terdapat seorang laki-laki ahli ibadah yang diuji perempuan pezina. Dimasukkanlah ia ke dalam kamar kemudian dikunci. Dihadapannya terdapat anak yang mengibakan. Kemudian disuruhlah ia untuk memilih diantara berzina, atau membunuh anak kecil atau meminum khamr. Dia pun kemudian memilih khamr. Dengan pilihannya tersebut kemudian dia berani untuk berzina dan membunuh anak-anak yang terdapat dalam kamar tersebut. Demikianlah sangat besar pengaruh dari khamr terhadap kemapanan akal, sehingga salah satu dari misi agama adalah memelihara akal (AlBantani, 2002).

Demikian ketat risalah Islam di dalam pemeliharaan akal ini, sehingga seseorang yang menodainya akan mendapat sanksi. Klaim bahwa pelaku yang menodai akal ini sebagai pelaku dosa besar dan perlu mendapat hukuman. Asy-Syaikh Al-Imam Al-Alim Al-Fadil Muhammad Nawawi AlJawi dalam kitab Margah Su'ud At-Tasdiq menyatakan bahwa pelakunya jika ia adalah orang yang merdeka adalah dijilid/dipukul empat puluh kali. Sedangkan bagi budak adalah setengahnya yaitu dipukul/dijilid dua puluh kali (A.-S. A.-I. A.-A. A.-F. M. N. Al-Jawi, n.d.).

3) Hak memelihara agama

Hak memelihara agama juga merupakan hak asasi bagi manusia. Karena manusia adalah makhluk yang lemah, yang memerlukan kekuatan dahsyat di luar dirinya. Kecenderungan ini dapat terlihat dalam kisah Nabi Ibrahim ketika mencari Tuhan dengan melihat pertama kepada bintang. Tetapi kemudian bintang pun terbenam. Dilanjutkan kemudian kedua penglihatannya kepada bulan, akan tetapi bulanpun terbenam pula. Dilanjutkan penglihatannya ketiga terhadap matahari, namun ia pun terbenam pula. Nabi Ibrahim menyakini bahwa Tuhan Yang Maha Hakiki tentunya tidak akan terbenam (Al-An'am: 77-81) (R. I. Departemen Agama, 2005). Meski situasi Ibrahim menjadi bahan diskusi para mufassirin tentang apakah benar Ia sedang menganalisa Tuhan atau apakah sedang melakukan tarbiyyah terhadap kaumnya, yang jelas penyembahan terhadap makhluk tidak dapat memberikan ketenteraman batin (Syakir, 2005). 
Risalah Islam menjamin hak kebebasan beragama (hifz ad-din). Di samping manusia adalah makhluk sosial manusia juga makhluk beragama. Status ini meniscayakan manusia sebagai makhluk yang percaya kepada Tuhan. Bagi umat Islam sejak Ia disebut mukallaf telah wajib baginya mengetahui akan sifat wajib, sifat mustahil dan sifat jaiz bagi-Nya (Mustafa, n.d.). Mengetahui pula bahwa tidak ada yang berhak disembah secara benar kecuali Tuhan Yang Maha Esa Allah SWT (S. N. Al-Jawi, n.d.). Beribadah merupakan aspek penting dalam keberagamaan seseorang, karenanya penghormatan atas keberadaan dan tata cara beribadah adalah hal yang penting. Ini pula merupakan hak asasi dari masing-masing pemeluk agama yang harus dihormati. Atas dasar inilah risalah Islam menanamkan prinsip umum terkait sikap keberagamaan seseorang yaitu tidak ada paksaan dalam agama (S. N. AlJawi, n.d.). sebagaimana Al-Baqarah ayat 256 artinya: Tidak ada paksaan untuk (memasuki) agama (Islam); Sesungguhnya telah jelas jalan yang benar daripada jalan yang sesat. karena itu barangsiapa yang ingkar kepada Tagut dan beriman kepada Allah, maka sesungguhnya ia telah berpegang kepada buhul tali yang amat kuat yang tidak akan putus, dan Allah Maha Mendengar lagi Maha Mengetahui.

Juga surat Yunus ayat 105 artinya: "Dan (aku telah diperintah): "Hadapkanlah mukamu kepada agama dengan tulus dan ikhlas dan janganlah kamu termasuk orang-orang yang musyrik."Juga surat Ar-Rum ayat 30 Artinya : "Maka hadapkanlah wajahmu dengan lurus kepada agama Allah; (tetaplah atas) fitrah Allah yang telah menciptakan manusia menurut fitrah itu. Tidak ada perubahan pada fitrah dan Allah. (Itulah) agama yang lurus; tetapi kebanyakan manusia tidak mengetahui.

Meskipun manusia dibebaskan dalam memilih agama, tetapi dalam ayat di atas terdapat penekanan dengan menggunakan kata ar-rusydu. Yaitu seseorang akan memilih agama yang benar, jika ia memiliki kecerdasan murni dan kedewasaan berfikir. Kebebasan beragama sejatinya adalah bentuk perhargaan Allah terhadap manusia sebagai hasil kreasinya yang paling baik dan sempurna, sekaligus juga realisasi sebagai makhluk yang bertanggung jawab (S. N. Al-Jawi, n.d.).

4) Hak berkeluarga

Sebagai upaya memakmurkan bumi dan menjadi khalifah fi al-ard, manusia disilahkan memiliki keturunan. Karena dari keturunan itulah kemudian akan terbentuk sebuah kebudayaan. Tugas suci sebagai khalifah akan dimulai dengan aktifitas suci yaitu dengan menikah. Tatacara akan pernikahan ini diatur oleh Allah dan Rasulnya melalui Al-Qur'an dan Hadis Rasulullah SAW (Departemen Agama, 2004). Hal ini dilakukan dalam rangka risalah Islam menjamin hak dan kesehatan reproduksi untuk membentuk keluarga (hifz an-nasl). Dalam surat An-Nisa' ayat 3 Allah berfirman artinya: “Dan jika kamu takut tidak akan dapat berlaku adil terhadap (hak-hak) perempuan yang yatim (bilamana kamu mengawininya), maka kawinilah wanita-wanita (lain) yang kamu senangi : dua, tiga atau empat. Kemudian jika kamu takut tidak akan dapat berlaku adil, maka (kawinilah) seorang saja, atau budakbudak yang kamu miliki. Yang demikian itu adalah lebih dekat kepada tidak berbuat aniaya (R. I. Departemen Agama, 2005).

Membina keluarga merupakan sifat naluriah dari manusia. Demikian juga meneruskan keturunan adalah salah satu hak asasi manusia. Guna membuat keluarga dan melangsungkan keturunan dalam risalah Islam dibahas dalam bab munakahat. Dalam aturan nikah bukan saja diatur masalah-masalah pasca nikah, Al-Qur'an surat ar-Rum ayat 21 menyatakan hal ini artinya: "Dan di antara tanda-tanda kekuasaan-Nya ialah Dia menciptakan untukmu isteri-isteri dari jenismu sendiri, supaya kamu cenderung dan merasa tenteram kepadanya, dan dijadikan-Nya diantaramu rasa kasih dan sayang. Sesungguhnya pada yang demikian itu benar-benar terdapat tanda-tanda bagi kaum yang berpikir.

Rasulullah SAW. menyebut nikah sebagai sunah Rasul dan bagi siapa saja yang membencinya dianggap bukan merupakan umatnya. Menikah untuk melangsungkan keturunan adalah hak setiap indifidu dan dilindungi hukum. Bahkan dalam beristri lebih dari satu pun termasuk yang diperbolehkan dalam risalah Islam, sepanjang pihak suami dapat memberikan nafkafnya secara adil (Al-Jaza'iri, 1976).

5) Hak kepemilikan harta Benda

Segala urusan dunia tidak akan kuat dan baik kecuali dengan harta benda. Sehingga oleh karenanya termasuk yang dilindungi oleh risalah Islam adalah adalah bahwa risalah Islam menjamin hak property (hifz al-mal). Termasuk hak mendapatkan pekerjaan, upah yang layak, jaminan 
perlindungan dan kesejahteraan (Al-Asqalanī, n.d.). Hak kepemilikan harta sangat dihargai oleh risalah Islam. Secara jelas Allah menyatakan alam semesta dan isinya diciptakan untuk dimanfaatkan manusia. Untuk itu manusia dibekali ilmu dan akal agar mereka mampu memanfaatkan bumi untuk keperluan pembangunan dan pelestarian. Sebagaimana dalam surat Al-Baqarah 29 dinyatakan artinya: "Dia-lah Allah, yang menjadikan segala yang ada di bumi untuk kamu dan Dia berkehendak (menciptakan) langit, lalu dijadikannya tujuh langit dan Dia Maha Mengetahui segala sesuatu." (R. I. Departemen Agama, 2005).

Manusia diberi hak untuk mengumpulkan harta dengan cara yang benar menikmati, mengembangkan harta itu demi kebaikan. Karena itu ia berhak mempertahankan harta itu dari orang lain. Rasulullah SAW. bersabda: "orang yang mati karena mempertahankan harta, sebagai syahid (Ni'mah, 2020) (H.R. Bukhari dan Muslim).

Deklarasi Universal HAM mewajibkan setiap Negara yang meratifikasikannya untuk melindungi seluruh warga negaranya dan memberi peluang kepada mereka untuk memiliki. Negara wajib melindungi warganya dari upaya-upaya pencabutan hak milik, baik oleh sesama warga maupun oleh Negara secara sewenang-wenang (Pratama, 2018).

Pada dasarnya setiap orang dilarang merampas harta benda orang lain. Harta harus didapat dengan jalan yang benar dan didistribusikan di jalan yang benar pula sehingga terwujud kedamaian. Hal ini sebagaimana ditegaskan Al-Qur'an dalam surat An-Nisa' 29 artinya: "Hai orang-orang yang beriman, janganlah kamu saling memakan harta sesamamu dengan jalan yang bat\}il, kecuali dengan jalan perniagaan yang berlaku dengan suka sama-suka di antara kamu dan janganlah kamu membunuh dirimu; Sesungguhnya Allah adalah Maha Penyayang kepadamu.

Juga ayat 188 surat Al-Baqarah artinya: Dan janganlah sebagian kamu memakan harta sebagian yang lain di antara kamu dengan jalan yang bat\}il dan (janganlah) kamu membawa (urusan) harta itu kepada hakim, supaya kamu dapat memakan sebagian daripada harta benda orang lain itu dengan (jalan berbuat) dosa, padahal kamu mengetahui.

Termasuk yang batil dalam mencari harta benda adalah mendapatkannya secara riba. Hal ini dilarang dalam Al-Qur' an surat Al-Baqarah pula ayat 275.

Orang-orang yang makan (mengambil) riba tidak dapat berdiri melainkan seperti berdirinya orang yang kemasukan syaitan lantaran (tekanan) penyakit gila.Keadaan mereka yang demikian itu, adalah disebabkan mereka berkata (berpendapat), sesungguhnya jual beli itu sama dengan riba, padahal Allah telah menghalalkan jual beli dan mengharamkan riba. Orang-orang yang telah sampai kepadanya larangan dari Tuhannya, lalu terus berhenti (dari mengambil riba), maka baginya apa yang telah diambilnya dahulu (sebelum datang larangan); dan urusannya (terserah) kepada Allah. orang yang kembali (mengambil riba), maka orang itu adalah penghuni-penghuni neraka; mereka kekal di dalamnya.

Masalah riba ini menjadi perhatian serius dalam risalah Islam. Ia digolongkan termasuk dosa besar setelah zina. Oleh karena itulah Rasulullah SAW, dengan keras menyatakan sebagaimana dikutip oleh pemilik kitab marqah su'ud at-tasdiq bahwa baik yang memakan, yang mewakili yang menulisi, yang menyaksikan semua dalam laknat Allah SWT (A.-S. A.-I. A.-'Alim A.-F. M. N. Al-Jawi, n.d.); (AlMalaybary, n.d.); (Al-Hisni, n.d.).

Termasuk dalam kategori hak milik adalah hak kekayaan intelektual. Hasil karya manusia dibidang keilmuan, kesenian, atau kesusasteraan menjadi hak cipta yang harus dilindungi. Hak cipta yaitu hak milik yang sah yang dilingdungi agama maupun hukum HAM. Setiap orang dilarang merampas hak itu tanpa izin. Perampasan atas hak cipta ini, pemiliknya berhak menuntut dan membawanya ke ranah hukum (A.-S. A.-I. A.-'Alim A.-F. M. N. Al-Jawi, n.d.).

Merupakan pakem dari risalah tersebut adalah Al-Quran. Al-Qur'an kemudian menjadi rujukan bagi terbangunnya peradaban baru yang sama-sekali berbeda dengan yang dulu. Ia akan melakukan pembangunan perdamaian di atas bumi ini. Jika bicara perdamaian, maka pendekatan pembangunan sebagai perdamaian, hendaknya jadikanlah prinsip dan nilai perdamaian baik dalam arti nir kekerasan maupun dalam arti upaya kreatif manusia untuk mencegah, menyelesaikan dan mentransformasi konflik sebagai acuan dasar dalam proses pembangunan. Berdasar prinsip dan nilai perdamaian ini, pembangunan diprioritaskan untuk menciptakan kondisi perdamaian melalui terpenuhinya 
kebutuhan dan hak-hak dasar dalam hidup warga Negara, sebagai upaya untuk mengatasi sumber konflik dan akar-akar kekerasan dalam masyarakat. Dilakukan dengan cara damai, sehingga tidak menimbulkan kerusakan, baik kehidupan sosial maupun lingkungan alam (Lambang, 2007).

Konsepsi pembangunan sebagai perdamaian menekankan pentingnya pembangunan sebagai sarana untuk mewujudkan perdamaian melalui pemenuhan kebutuhan dan hak-hak dasar dalam hidup: kesejahteraan, kebebasan, kaamanan, dan identitas budaya. Terpenuhinya keempat kebutuhan dan hak-hak dasar dalam hidup ini akan membebaskan warga dari penderitaan, kekerasan baik struktural maupun kultural seperti kemiskinan, represi ketidaknyamanan dan aliensi budaya yang dalam banyak kasus menjadi sumber utama terjadinya konflik dan gejolak politik di masyarakat (Lambang, 2007).

Sebagai upaya untuk mewujudkan perdamain dibumi ini, dari sisi ekonomi manusia telah diberi modal oleh Allah SWT berupa Alam semesta. Alam semesta yang kita hidup di dalamnya ini diciptakan Allah Swt, secara sistematis mekanis. Satu dengan lainnya saling berhubungan dan bekerja secara otomatis. Nasi yang kita makan sehari-hari tidaklah ada begitu saja, tetapi tidak lepas dari peran petani. Petani juga tidak bisa bekerja sendiri tanpa bantuan tukang traktor, juru tanam, tukang pupuk dan lain-lain. Sudah ditanam, tapi tidak dipupuk, tanaman akan kurus. Demikian itulah telah diatur oleh Allah Swt, secara mekanik, sehingga semuanya harus bekerja dan berfungsi secara baik agar tidak terjadi masalah dalam sistem tersebut. Kerja mekanik yang tersistem itulah disebut sunatullah (Shihab, 1996). Dalam Al-Quran surat Al-Fath ayat 23 disebutkan artinya: "tidak akan ada yang bisa mengubah sunah Allah sebagai penggantinya." (R. I. Departemen Agama, 2005).

Tampaknya keteraturan yang digagas oleh Allah Swt adalah sebuah isyarat bahwa manusia memang tidak bisa hidup secara sendiri, tetapi harus memerlukan orang lain. Justeru di sinilah keindahan dari hidup itu dapat terwujud dengan dinamis. Setiap kita akan bekerja pada keterampilan kita masing-masing. Al-Quran menyatakan hal ini dalam surat Al-Isra' ayat 84 artinya: "Katakanlah: tiap-tiap orang berbuat menurut keadaannya masing-masing". Maka Tuhanmu lebih mengetahui siapa yang lebih benar jalannya (R. I. Departemen Agama, 2005).

Keanekaragaman adalah merupakan barakah yang luar biasa. Dapat dibayangkan oleh kita betapa akan sangat jenuh jika kita dikungkung dalam dinding-dinding format tertentu. Dengan perbedaan ini manusia dapat menyadari kekurangan dan kelebihan dari yang lain. Perbedaan kemapanan ini juga secara tidak langsung adalah agar saling mengenal. Dari sinilah lahir tolong-menolong agar menjadi sebuah ibadah (Sinaga, 2020). Dalam hidup bersama berlakulah adanya hak dan kewajiban.

a) Hak-Hak Asasi Manusia.

Diantara makhluk Allah Swt. yang paling sempurna adalah manusia. Ia diciptakan sebaik-baik ciptaan (ahsani taqwim). Meski demikian keberadaannya tidak lepas dari yang lain. Fulan dengan kelahirannya telah ditolong oleh bidan, dukun bayi, dan saudara-saudara dekat. Masih pula didukung oleh adanya alat-alat medis yang memperlancar adanya suatu kelahiran dengan instrumen-instrumen yang dihasilkan dari rekayasa-rekayasa berbagai profesi yang berbeda. Hubungan ini melahirkan suatu relasi dan strata sosial yang ada. Di sana terdapat hubungan orang tua dengan anak, suami dengan isteri, kakak dengan adik, dokter dengan para medis. Semua itu meniscayakan adanya hak dan kewajiban yang harus dipenuhi masing-masing pihak (R. I. Departemen Agama, 2005).

(1) Keseimbangan Hidup.

Keberadaan alam semesta ini bukanlah kebetulan, tidak disengaja ataupun main-main. Akan tetapi adanya adalah hal yang diciptakan dengan penuh keteraturan, tertata tanpa adanya pertentangan dan dengan penuh mekanisme yang stabil dan seimbang. Mereka semua tunduk atas sunnatullah dan bertasbih kepadanya. Hal ini seperti dalam Al-Quran surat Al-Hasyr ayat 24 "Bertasbih kepada Allah segala sesuatu yang ada di langit dan di bumi" (R. I. Departemen Agama, 2005). Demikian pula manusia. Dicipta oleh Allah dengan penuh mekanisme biologis yang seimbang, sehingga manusia dikatakan oleh Allah sebagai ahsani taqwim. Dalam surat Al-Infitar ayat 7 Allah berfirman artinya: Yang telah menciptakan kamu lalu menyempurnakan kejadianmu dan menjadikanmu (susunan tubuhmu) seimbang (R. I. Departemen Agama, 2005). Dalam kehidupan sosial, ekonomi, budaya bahkan spiritualpun memerlukan adanya keseimbangan (at-tawazun). Manusia yang sehat adalah mereka yang mampu 
menjaga keseimbangan ini. Baik keseimbangan lahiriah individu (fardiyah) maupun kelompok sosial (jam'iyyah), antara kehidupan duniawi maupun dengan ukhrawi sebagaimana dijelaskan Allah dalam surat Al-Qasas ayat 77 artinya: "Dan carilah pada apa yang telah dianugerahkan Allah kepadamu (kebahagiaan) negeri akhirat, dan janganlah kamu melupakan bahagianmu dari (kenikmatan) duniawi dan berbuat baiklah (kepada orang lain) sebagaimana Allah telah berbuat baik, kepadamu, dan janganlah kamu berbuat kerusakan di (muka) bumi. Sesungguhnya Allah tidak menyukai orang-orang yang berbuat kerusakan." (R. I. Departemen Agama, 2005).

Kandungan ayat di atas mengandung spirit keseimbangan dunia dan akhirat. Tidak boleh ada yang ekstrem diantara keduanya. Karena pada umumnya yang ekstrem membawa negatif. Kehidupan ini haruslah seimbang antara fisik dan psikhis, jasmani dan rokhani hak dan kewajiban, dunia dan akhirat, meskipun akhirat itu lebih utama dan lebih langgeng. Manusia harus bekerja optimal dalam rangka meraih dunianya, tetapi tidak boleh melupakan akhirat. Karena akhirat adalah tempat kembalinya. Dunia menjadi washilah baik kehidupannya di akhirat. Rasulullah bersabda artinya: "dunia adalah ladang tempat menanam buah akhirat." (R. I. Departemen Agama, 2005).

Keseimbangan dapat juga dipahami sebagai bekerjanya seluruh dari komponen di dalam kehidupan ini. Stroke adalah gejala tidak bekerjanya organ di bagian tertentu dari tubuh manusia yang mengakibatkan gerak dari jalan seseorang menjadi pincang akibat gangguan tersebut. Sebagai contoh adalah jam sebagai pengatur waktu ia memiliki jarum besar dan kecil. Jika jarum jam itu berputar berlawanan dengan jarum yang lain, maka akan terjadi kekacauan dengan tidak menunjuk pada waktu yang tepat (R. I. Departemen Agama, 2005).

Di dalam Al-Quran Allah Swt. menegaskan agar manusia hidup dengan penuh keseimbangan dengan cara berperilaku adil, moderat, tidak menzalimi orang lain, tidak curang dalam mencari harta, tidak mengurangi timbangan dan takaran pihak lain. Hal ini dimaksudkan agar manusia hidup bermasyarakat secara damai, bermartabat dan diridai oleh Allah Swt (R. I. Departemen Agama, 2005).

(2) Perintah berlaku adil.

Dalam kehidupan sosial sikap adil perlu ditegakkan. Hal ini dilakukan guna membangun harmoni antar komponen dalam masyarakat. Sikap adil ini membutuhkan perjuangan khususnya ketika terdapat kebencian terhadap suatu kelompok masyarakat atau sebaliknya, kecintaan yang diakibatkan oleh pertemanan atau lainnya (Al-Mas'udiy, n.d.).

Menurut Syaihk Azhar Ada dua model keadilan yaitu: pertama, keadilan terhadap diri sendiri dengan senantiasa hidup yang istiqamah. Kedua keadilan terhadap orang lain meliputi: pertama, keadilan pemerintah terhadap rakyatnya dengan cara memberikan kemudahan dan menyampaikan hak-haknya. Kedua keadilan rakyat beserta pemerintahnya, murid sama gurunya anak serta kedua orang tuanya dengan ikhlas dan taat. Ketiga keadilan manusia dengan sesamanya dengan tidak sombong dan tidak menyakiti mereka (Al-Mas'udiy, n.d.).

Keadilan itu harus senantiasa ditegakkan meskipun terhadap diri sendiri. Al-Qur'an surat AlMaidah ayat 8 menerangkan hal ini artinya: "Hai orang-orang yang beriman hendaklah kamu jadi orangorang yang selalu menegakkan (kebenaran) karena Allah, menjadi saksi dengan adil. dan janganlah sekali-kali kebencianmu terhadap sesuatu kaum, mendorong kamu untuk berlaku tidak adil. Berlaku adillah, karena adil itu lebih dekat kepada takwa. dan bertakwalah kepada Allah, Sesungguhnya Allah Maha Mengetahui apa yang kamu kerjakan (R. I. Departemen Agama, 2005).

Hadis atau riwayat Aisyah bahwa Rasulullah Saw. bersabda: "apakah kamu akan memberi syafa' at terhadap suatu hukum had dari hukum-hukum had-nya Allah Swt. Kemudian beliau berdiri, lalu berkhutbah seraya berkata: "wahai manusia, sesungguhnya orang-orang sebelum kalian telah binasa disebabkan bahwasanya mereka, bila ada seorang dari golongan terhormat di antara mereka yang mencuri, mereka membiarkannya, dan bila ada seorang dari golongan rendah mencuri, mereka akan melaksanakan hukuman had terhadapnya. Hadis Rasulullah Saw. ini mendorong berbuat adil dan berdimensi rahmah. Karena dengan inzar bahwa orang dahulu rusak karena tidak adil memberikan peringatan dan semangat agar dapat berlaku adil, karena hal itu lebih menyenangkan, kepada semua pihak (al-Asqalani, n.d.; Al-Asqalani, 2015). 
(3) Moderat

Sikap moderat diperlukan juga dalam rangka menjaga harmoni kehidupan baik sebagai indifidu maupun kelompok masyarakat. Sikap moderat ini harus dibangun bahkan merambah ke berbagai hal termasuk dalam hal berinfak sekalipun seperti dalam surat Al-Furqan ayat 67 artinya: "Dan orang-orang yang apabila membelanjakan (harta), mereka tidak berlebihan, dan tidak (pula) kikir, dan adalah (pembelanjaan itu) di tengah-tengah antara yang demikian." (R. I. Departemen Agama, 2005). Umat Islam memang terlahir guna memotori lahirnya moderasi. Dalam Al-Quran surat Al-Baqarah 143 disebutkan artinya ; Dan demikian (pula) Kami telah menjadikan kamu (umat Islam), umat yang adil dan pilihan agar kamu menjadi saksi atas (perbuatan) manusia dan agar Rasul (Muhammad) menjadi saksi atas perbuatan kamu... (R. I. Departemen Agama, 2005).

Dalam hadis disebutkan khairu Al-umuri ausatuha. Artinya: "Sebaik-baik perkara adalah tengahtengah."

(4) Larangan memakan harta benda orang lain secara tidak wajar atau batil.

Meski pun harta benda merupakan sarana manusia hidup di dunia, akan tetapi cara mendapatkannya haruslah dengan cara-cara yang dibenarkan oleh Syara'. Sahabat Ali RA. Menyatakan bahwa mulianya seseorang yang hidup di dunia adalah dengan banyaknya harta benda (M. N. I. U. Al-Jawi, n.d.). Namun demikian cara mendapatkannya dengan cara yang benar. Mendapatkan harta dengan cara yang tidak benar dilarang oleh Allah Swt. Sebagaimana tersurat dalam Al-Baqarah ayat 188 artinya: "Dan janganlah sebagian kamu memakan harta sebagian yang lain di antara kamu dengan jalan yang bat\}il dan (janganlah) kamu membawa (urusan) harta itu kepada hakim, supaya kamu dapat memakan sebagian daripada harta benda orang lain itu dengan (jalan berbuat) dosa, padahal kamu mengetahui." (R. I. Departemen Agama, 2005).

Rasulullah Saw. bersabda: Siapa yang mengambil harta untuk disampaikan kepada yang berhak, maka Allah akan menyampaikannya, dan siapa yang mengambil barang orang lain untuk melenyapkannya, maka Allah akan melenyapkannya ('Imarah, n.d.).

(5) Larangan menzalimi orang lain.

Islam melarang umatnya berbuat zalim kepada pihak lain dengan segala macamnya. Berbuat zalim kepada orang lain identik dengan merampas hak orang lain. Salah satu kezaliman yang tersamar namun banyak terjadi adalah pengurangan dalam timbangan dan takaran. Hal ini sebagaiman ditegaskan dalam Al-Quran surat Al-Mutaffifin 1-3 sebagai berikut: 1. Kecelakaan besarlah bagi orangorang yang curang, 2. (yaitu) orang-orang yang apabila menerima takaran dari orang lain mereka minta dipenuhi, 3. Dan apabila mereka menakar atau menimbang untuk orang lain, mereka mengurangi ('Imarah, n.d.).

Rasulullah Saw. bersabda: "Menimbanglah kamu sekalian hingga terpenuhi timbangan." ('Imarah, n.d.).

Untuk dapat terpenuhinya timbangan-timbangan sebagaimana tersurat dalam hadis, maka tidak bisa lepas dari terpenuhinya kewajiban-kewajiban dan hak-hak. Jika Hak-hak asasi telah dibahas pada uraian di atas, maka selanjutnya adalah masalah kewajiban asasi manusi.

a. Kewajiban Asasi Manusia.

Pada umumnya masyarakat dunia menuntut hak asasi manusia. Sebagai contoh adalah deklarasi hak asasi manusia. Tetapi jarang terdengar adanya penyadaran terhadap kewajiban asasi manusia. Padahal hal ini sangat penting. Karena pemenuhan atas kewajiban sebagai makhluk terhadap khalik akan berdampak positif pada terpenuhinya pula hak-hak terhadap yang lain ('Imarah, n.d.).

Kewajiban asasi manusia itu dapat diklasifikasikan kepada lima hal sebagai berikut:

1) Kewajiban kepada Allah dan Rasulnya (Al-Jabbar, n.d.).

Kehadiran manusia ke dunia ini bukanlah kemauan dari manusia itu sendiri, orang tua, atau lainnya tetapi karena Allah Swt. Terdapat maksud-maksud tertentu dibalik penciptaan manusia itu. Yaitu dalam rangka menyembah/beribadah kepada-Nya (Abdul Wahhab, n.d.). Sebagaimana disebutkan Al-Quran dalm surat Al-Dzariyat ayat 56 Artinya: "Dan aku tidak menciptakan jin dan manusia melainkan supaya mereka mengabdi kepada-Ku." (R. I. Departemen Agama, 2005). 
Allah juga telah mencukupi segalanya. Hal ini sebagaimana tersurat dalam surat Hud ayat 6 Artinya: "Dan tidak ada suatu binatang melata pun di bumi melainkan Allah-lah yang memberi rezkinya, dan Dia mengetahui tempat berdiam binatang itu dan tempat penyimpanannya. semuanya tertulis dalam kitab yang nyata (Lauh Mahfuz) (R. I. Departemen Agama, 2005). Bahwa manusia mendapatkan pertolongan dari sesama adalah datangnya kemudian adanya. Oleh karena itu kewajiban asasi manusia yang harus diprioritaskan adalah kepada Tuhan pemberi hidup Yang Maha segalanya baru kemudian yang lain. Kewajiban asasi manusia adalah mengesakan, mengabdi dan taat kepadaNya. Allah memperkenalkan diri agar manusia menyembahnya pada surat Taha ayat 14 artinya: "Sesungguhnya aku ini adalah Allah, tidak ada Tuhan (yang hak) selain Aku, Maka sembahlah aku dan dirikanlah shalat untuk mengingat aku." (R. I. Departemen Agama, 2005).

Hadis riwayat Bukhari dan Muslim dari Mu'adz bin Jabal menerangkan hubungan hak dan kewajiban manusia sebagai makhluk dan Allah sebagai Khalik sebagai berikut: Dari Mu'adz bin Jabal ia berkata: Suatu saat aku naik Khimar (yang dipanggil ‘Ufair) dan duduk dibelakang Rasulullah Saw. Tiba-tiba Nabi bertanya kepadaku: Hai Mu'adz tahukah kamu hak hak Allah atas hambanya dan hak hamba atas Allah? Aku menjawab Allah dan Rasulnya lebih mengetahui: lalu Nabi menjelaskan: Hak Allah atas hambanya adalah hamba menyembahNya tanpa menyekutukan-Nya dengan sesuatu apapun, sedangkan hak hamba atas Allah adalah Allah tidak akan menyiksa hamba yang tidak menyekutukan-Nya. Aku bertanya: Wahai Rasulullah apa tidak sebaiknya aku sebarkan berita gembira ini kepada manusia? Beliau menjawab: sebaiknya tidak, karena mereka nanti akan berpangku tangan (malas beribadah) HR. Bukhari Muslim dari Mu'adz ('Imarah, n.d.).

Selain kewajiban asasi manusia kepada Allah, juga kepada Rasulullah. Sebagai tanda atas pemenuhan kewajiban terhadap Rasul adalah taat dan mencintainya.Dengan cara begitu maka Seseorang akan meraih cinta Allah. Karena hubungan Allah dan RasulNya ibarat satu mata uang satu dengan yang lainnya tidak bisa dipisahkan ('Imarah, n.d.). Hal ini sebagaimana disebutkan dalam AlQuran surat Ali ‘Imran ayat 31 Artinya: "Katakanlah: "Jika kamu (benar-benar) mencintai Allah, ikutilah Aku, niscaya Allah mengasihi dan mengampuni dosa-dosamu." Allah Maha Pengampun lagi Maha Penyayang." (R. I. Departemen Agama, 2005).

2) Kewajiban Terhadap Diri Sendiri

Hidup dan kehidupan adalah anugerah Allah Swt. Dalam doa iftitah yang dibaca sebagian umat Islam bahwa shalat, ibadah, hidup dan mati adalah karena Allah Swt. Oleh karena itu sebuah anugerah, maka kewajiban asasi bagi manusia adalah memelihara. Al-Quran melarang mencederai atau mencelakai diri sendiri baik secara pisik maupun psikis. Hal ini sebagaimana tersurat dalam AlBaqarah ayat 195 artinya: Dan belanjakanlah (harta bendamu) di jalan Allah, dan janganlah kamu menjatuhkan dirimu sendiri ke dalam kebinasaan, dan berbuat baiklah, karena Sesungguhnya Allah menyukai orang-orang yang berbuat baik (R. I. Departemen Agama, 2005).

Diantara kegiatan menjaga kelangsungan hidup adalah dengan menjaga kesehatan, menjamin organ tubuh mendapatkan hak-haknya secara adil seperti halnya mata harus tidur, dan menghindarkan diri dari segala sesuatu yang merusak kelangsungan dan tatanan hidup. Berhubungan dengan ini Rasulullah Saw bersabda melalui riwayat Abdullah bin Amr. Bahwa Rasulullah bertanya kepadaku: wahai Abdullah: "Aku mendapat kabar apakah benar bahwa engkau berpuasa di siang hari terus-menerus dan shalat terus sepanjang malam? Aku Menjawab: "Benar ya Rasulullah." Rasul menasihati: "jangan begitu, shalat dan puasalah lalu berbuka, bangun malam salat dan tidurlah, karena sesungguhnya jasad, mata, istri dan keluargamu juga punya hak dari engkau. Cukuplah engkau berpuasa tiga hari setiap bulan, karena sesunguhnya setiap satu kebaikan, maka itu (puasa tiga hari) sama halnya dengan puasa sepanjang masa (R. I. Departemen Agama, 2005).

3) Kewajiban Kepada Sesama Manusia.

Kewajiban kepada sesama manusia sangat luas meliputi kewajiban kepada orang tua, keluarga, pasangan (suami/istri) karib kerabat, tetangga, guru, teman, tamu dan lain sebagainya (Kementerian Agama, 2014).

Secara garis besar kewajiban tersebut dapat diuraikan sebagai berikut: 
a) Kewajiban asasi kepada orang tua

Kedua orang tua adalah merupakan sebab dari adanya manusia. Tanpa adanya perhatian dan kasih sayang mereka mustahil kita dapat hidup enak. Ibu dengan susah payah mengandungnya selama sembilan bulan sepuluh hari dan telah menyusuinya. Adapun ayah maka telah mencurahkan segala kemampuannya untuk kemanfaatan kita dalam rangka membangun jasmani dan ruhani kita (AlMas'udiy, n.d.). Kewajban asasi kepada orang tua adalah berbuat baik dan mematuhi perintahnya, selama tidak bertentangan dengan perintah Allah dan Rasul-Nya. Hal ini tersimpul di dalam surat AlIsra' 23-24 artinya:

"Dan Tuhanmu telah memerintahkan supaya kamu jangan menyembah selain Dia dan hendaklah kamu berbuat baik pada ibu bapakmu dengan sebaik-baiknya. jika salah seorang di antara keduanya atau Keduaduanya sampai berumur lanjut dalam pemeliharaanmu, Maka sekali-kali janganlah kamu mengatakan kepada keduanya Perkataan "ah" dan janganlah kamu membentak mereka dan ucapkanlah kepada mereka Perkataan yang mulia."

"Dan rendahkanlah dirimu terhadap mereka berdua dengan penuh kesayangan dan ucapkanlah: "Wahai Tuhanku, kasihilah mereka keduanya, sebagaimana mereka berdua telah mendidik aku waktu kecil" ('Imarah, n.d.).

Dalam hadis riwayat Abu Hurairah bahwa terdapat seorang laki-laki yang menghadap Rasulullah dan bertanya: Siapakah yang lebih berhak aku temani? Rasul menjawab Ibumu. Lalu Siapa? Rasul menjawab Ibu. Lalu siapa? Ibumu, kemudian ayahmu ('Imarah, n.d.).

Dalam hadis di atas ibu disebut lebih dari satu kali daripada ayah. Hal ini menyiratkan bahwa pertemanan dengan Ibu adalah seyogyanya lebih daripada ayah. Hafiz Hasan Al-Mas'udiy seorang ulama Azhar menyatakan bahwa kebaikan kita kepada Ibu hendaklah ditambah seiring dengan adanya hadis Rasul "bahwa kebajikan terhadap Ibu bagi anak adalah dua kali lipat." (Al-Mas'udiy, n.d.).

b) Kewajiban Suami Istri

Kewajiban suami istri secara timbal balik adalah bergaul dengan baik (mu'asyarah bi al-ma'ruf) dan menjaga kehormatan masing-masing hal ini sebagaimana tersurat dalam An-Nisa' ayat 19 artinya (AlMas'udiy, n.d.):

"Hai orang-orang yang beriman, tidak halal bagi kamu mempusakai wanita dengan jalan paksa dan janganlah kamu menyusahkan mereka karena hendak mengambil kembali sebagian dari apa yang telah kamu berikan kepadanya, terkecuali bila mereka melakukan pekerjaan keji yang nyata dan bergaullah dengan mereka secara patut. kemudian bila kamu tidak menyukai mereka, (maka bersabarlah) karena mungkin kamu tidak menyukai sesuatu, padahal Allah menjadikan padanya kebaikan yang banyak."(R. I. Departemen Agama, 2005).

Dalam hadis riwayat Abdullah Ibnu Zam'ah disebutkan bahwa Rasulullah bersabda: janganlah seorang kamu mengajar istrinya sebagaimana mengajar hamba sahaya, kemudian menjamahnya di akhir hari. Hadis ini menerangkan bahwa meskipun seorang-laki-laki marah, jengkel tidak boleh memukul hingga melukai tubuhnya. Apalagi kemudian di pagi harinya meminta untuk hubungan intim. Meskipun ayat di atas yang menjadi khitab langsung (menggunakan perangkat laki-laki, tetapi bukan berarti bergaul itu cuma laki-laki tetapi juga sebaliknya perempuan juga bermu'amalah dengan suami dengan baik.

c) Kewajiban terhadap karib, kerabat, teman, tetangga, dan orang-orang yang kurang beruntung secara ekonomi

Para karib kerabat adalah mereka yang memiliki hubungan keluarga. Allah SWT memerintahkan kepada kita agar menyambung tali shilaturrahmi kepada mereka. Hendaklah kita memelihara hak-hak mereka. Maka tidak boleh melukai perasaan mereka baik ucapan maupun perbuatan (Al-Mas'udiy, n.d.). Antara lain berbuat baik sesuai kondisi masing-masing. Dalam surat An-Nisa' ayat 36 Allah meminta perhatian dan kepedulian (Al-Mas'udiy, n.d.) sebagai berikut artinya:

"Sembahlah Allah dan janganlah kamu mempersekutukan-Nya dengan sesuatupun, dan berbuat baiklah kepada dua orang ibu-bapak, karib-kerabat, anak-anak yatim, orang-orang miskin, tetangga yang dekat dan tetangga yang jauh dan teman sejawat, Ibnu sabil dan hamba sahayamu. 
Sesungguhnya Allah tidak menyukai orang-orang yang sombong dan membangga-banggakan diri (Al-Mas'udiy, n.d.).

d) Kewajiban kepada sesama manusia pada umumnya, khususnya kepada sesama muslim, dengan menunaikan hak-haknya dengan baik

Terdapat banyak sekali etika yang berkait dengan kewajiban terhadap sesama manusia ini. Antara lain adalah tampilan wajah yang berseri tidak masam. Tidak angkuh dan sombong. Tidak menyombongkan diri dengan harta dan kedudukan karena hal itu justeru akan menjatuhkan diri di tengah-tengah pandangan manusia secara umum (Al-Mas'udiy, n.d.).

Beberapa hadis menerangkan hak dan antara seorang muslim dengan muslim lainnya diantara sebagai berikut: "Dalam hadis riwayat Safwan Ibnu Muhrizi Al-Mazini bahwa Rasulullah bersabda seorang muslim adalah saudara bagi muslim lainnya. Tidak boleh menzalimi, tidak mencaci, menghina, Siapa yang membantu hajat saudaranya maka Allah akan menunaikan hajatnya, siapa yang membukakan kegalauan seseorang maka ia akan dibukakan oleh Allah Swt di hari Qiyamat dan siapa yang menutupi kekurangan seorang muslim, maka Allah akan menutupinya di hari Qiyamat" ('Imarah, n.d.).

e) Kewajiban kepada Negara dan pemerintah

Suatu hal yang tidak dapat dipungkiri bahwa kita mendiami suatu territorial yang memberi batasan-batas sebuah wilayah untuk memudahkan identitas. Wilayah itu di Indonesia, dimulai dari RT, RW, desa/kelurahan, kecamatan, kabupaten/kota, Provinsi dan NKRI. Ada pemerintah yang mendapat legitimasi untuk memimpin rakyat dalam rangka memperoleh keadilan dan kesejahteraan lahir dan batin. Kewajiban warga adalah menaati peraturan-peraturan yang digariskan oleh Negara sepanjang tidak bertentangan dengan hukum-hukum Allah Swt. Seperti halnya memerintahkan berbuat maksiat ('Imarah, n.d.).

Surat An-Nisa' ayat 59 sering digunakan dalam rangka menerangkan hal ini artinya: "Hai orangorang yang beriman, taatilah Allah dan taatilah Rasul-Nya, dan ulil amri di antara kamu. Kemudian jika kamu berlainan pendapat tentang sesuatu, maka kembalikanlah ia kepada Allah (Al-Quran) dan Rasul (sunnahnya), jika kamu benar-benar beriman kepada Allah dan hari kemudian. Yang demikian itu lebih utama (bagimu) dan lebih baik akibatnya".

f) Kewajiban terhadap lingkungan hidup

Meskipun semua yang ada diperuntukkan bagi manusia dalam rangka ibadah kepada Allah Swt, bukan berarti bahwa manusia bebas mengekploitasi. Memelihara dan melestarikan adalah tugas manusia. Di darat, laut, maupun udara bertebaran makhluk Allah, yang memiliki andil dalam membentuk ekosistem yang teratur. Terdapat tidak sedikit ayat Al-Quran yang melarang manusia berbuat kerusakan. Karena alam ini diciptakan dengan penuh keteraturan dan keseimbangan. Terjadinya kerusakan boleh jadi akibat ulah manusia. Sehingga untuk menjaganya disampaikan larangan berbuat kerusakan ('Imarah, n.d.).

Hal ini sebagaimana ayat 56 surat Al-A'raf artinya: Dan janganlah kamu membuat kerusakan di muka bumi, sesudah (Allah) memperbaikinya dan Berdoalah kepada-Nya dengan rasa takut (tidak akan diterima) dan harapan (akan dikabulkan). Sesungguhnya rahmat Allah Amat dekat kepada orang-orang yang berbuat baik (R. I. Departemen Agama, 2005). Flora dan fauna yang ada diciptakan oleh Allah untuk kebutuhan manusia. Sebagai lazimnya, ia membutuhkan lahan untuk berkembang seperti udara, air, sinar matahari dan makanan. Kalaupun karena kebutuhan protein hewani harus memakan daging, dalam penyembelihannya pun harus dilakukan dengan penuh rahmat yaitu sesuai syari'at dengan menggunakan pisau yang tajam ('Imarah, n.d.).

\section{Rahmatan li Al-Alamin Hubungannya Dengan Keberagaman Umat Beragama}

Pemerintah menyadari bahwa keanekaragaman suku, adat istiadat dan agama merupakan suatu kenyataan yang harus disyukuri bersama. Meski demikian kemajemukan atau keanekaragaman dapat pula mengandung kerawanan-kerawanan sosial yang dapat memunculkan konflik-konflik kepentingan antar kelompok yang berbeda-beda. Untuk menanggulangi kemungkinan terjadinya kerawanan sosial tersebut pemerintah telah melakukan upaya-upaya preventif dengan pembinaan kerukunan antar umat beragama melalui suatu proyek di Departemen Agama, yaitu Proyek 
Peningkatan Kerukunan Hidup Umat Beragama yang sebelumnya bernama Proyek Pembinaan Kerukunan Hidup Umat Beragama (Abdullah, 1994).

Dalam terminologi yang digunakan Pemerintah bahwa konsep kerukunan hidup beragama itu mencakup tiga kerukunan yaitu: kerukunan intern umat beragama, kerukunan antar umat yang berbeda-beda agama, dan kerukunan antara (pemuka) dan umat beragama dengan Pemerintah. Tiga kerukunan tersebut biasa disebut dengan tri kerukunan (Abdullah, 1994).

\section{Kerukunan Intern Umat Beragama}

Untuk menjaga stabilitas nasional diantaranya adalah menjaga kerukunan intern umat beragama. Sebagai penganut agama yang sama, seperti Islam dengan Islam mereka adalah saudara seagama. Demikian juga Kristen dengan Kristen, dan seterusnya. Sehingga hendaklah mereka bersatu tidak saling ejek, tetapi justru saling asah, asih dan asuh. Hindari hal-hal khilafiyah yang memungkinkan timbulnya perselisihan di internal umat seagama (Abdullah, 1994). Kalaupun terdapat perbedaan hendaklah bisa diminimalisasi dan dapat dipahami bersama sebagai sebuah rahmah dan hasanah. Seperti do'a qunut, azan dua ketika akan salat jum'at dan lain-lain yang sifatnya khilafiyah. Di sini lah berlaku kaidah lana a'maluna wa lakum a'malukum. Bagi kami amal kami dan bagimu amal kamu sekalian (Chalim, 2018).

Dalam surat al-Fath ayat 29 Allah berfirman artinya: Muhammad itu adalah utusan Allah dan orang-orang yang bersama dengan Dia adalah keras terhadap orang-orang kafir, tetapi berkasih sayang sesama mereka. kamu Lihat mereka ruku' dan sujud mencari karunia Allah dan keridhaan-Nya, tandatanda mereka tampak pada muka mereka dari bekas sujud. Demikianlah sifat-sifat mereka dalam Taurat dan sifat-sifat mereka dalam Injil, Yaitu seperti tanaman yang mengeluarkan tunasnya Maka tunas itu menjadikan tanaman itu kuat lalu menjadi besarlah Dia dan tegak Lurus di atas pokoknya; tanaman itu menyenangkan hati penanam-penanamnya karena Allah hendak menjengkelkan hati orang-orang kafir (dengan kekuatan orang-orang mukmin). Allah menjanjikan kepada orang-orang yang beriman dan mengerjakan amal yang saleh di antara mereka ampunan dan pahala yang besar.

Ibnu Kasir sebagaimana ditahkik oleh Ahmad Muhammad Muhammad Syakir menyatakan bahwa melalui ayat ini Allah SWT mengabarkan bahwa kedudukan Nabi Muhammad Adalah utusan Allah yang benar dan tidak diragukan lagi. Orang-orang yang mengitarinya dari kalangan para sahabat juga mereka dipuji oleh Allah SWT karena sifatnya yang agung. Yaitu berkasih sayang dengan sesama orang yang beriman, tetapi benci dan dapat saja bengis terhadap orang kafir. Mentalitas orang beriman yang mengasihi seagamanya merupakan proyeksi dari Allah SWT (Syakir, 2005). Dalam surat al-Maidah 54 Allah berfirman artinya:

Hai orang-orang yang beriman, Barangsiapa di antara kamu yang murtad dari agamanya, Maka kelak Allah akan mendatangkan suatu kaum yang Allah mencintai mereka dan merekapun mencintaiNya, yang bersikap lemah lembut terhadap orang yang mukmin, yang bersikap keras terhadap orang-orang kafir, yang berjihad dijalan Allah, dan yang tidak takut kepada celaan orang yang suka mencela. Itulah karunia Allah, diberikanNya kepada siapa yang dikehendaki-Nya, dan Allah Maha Luas (pemberian-Nya), lagi Maha mengetahui.

Yaitu bahwa mereka orang-orang yang beriman dicintai oleh Allah dan Allah juga cinta kepada mereka karena perangai mereka yang solid dengan orang-orang seagamanya. Digambarkan oleh Nabi SAW bahwa kehidupan orang-orang yang beriman dalam masalah cinta kasih dan kasih sayang laksana tubuh yang satu, hal mana jika terdapat anggota badan yang sakit, maka demamlah seluruh tubuh dengan panas dan stress (Shofaussamawati, 2017).

Dalam surat al-Hujurat ayat 10 Allah berfirman artinya: "Orang-orang beriman itu Sesungguhnya bersaudara. sebab itu damaikanlah (perbaikilah hubungan) antara kedua saudaramu itu dan takutlah terhadap Allah, supaya kamu mendapat rahmat."

Ahmad Muhammad Syakir ketika menafsirkan ayat 10 surat al-Hujurat mengatakan bahwa umat Islam keseluruhannya adalah merupakan saudara seagama. Sebagaimana sabda Rasul bahwa seorang muslim adalah saudara muslim lainnya. Oleh karena itu, Allah akan senantiasa menolong seseorang selama ia menolang saudaranya. Bahkan do'a seseorang kepada orang lain seagama haruslah senantiasa baik, karena diaminkan oleh malaikat, dan dipulangkan juga apa yang dia panjatkan dalam 
do'a. Oleh karena itu apapun yang terjadi sebagai sebuah konflik dalam intern umat Islam hendaklah didamaikan. Bahkan terdapat penekanan bahwa rahmat akan diperoleh ketika mampu mewujudkan kedamaian antar sesama muslim (Syakir, 2005).

Orang-orang yang beriman disifatkan dengan yang rajin beramal dan rajin ibadah seperti halnya salat yang merupakan sebaik-baik dari ibadah. Juga disifati dengan ikhlas dan berharap pahala dari Allah SWT. Berupa sorga yang memuat berbagai macam dari keutamaan yang diberikan Allah SWT. Mereka diluaskan rizkinya oleh Allah SWT, dan keridaan yang diberikan adalah sebesar-besar karunia. Kondisi mereka yang rajin beribadah itu tercermin dalam sikap hidupnya yang khusyu' dan tawaddu (Shofaussamawati, 2017).

\section{Kerukunan Antar Umat Beragama}

Penghayatan terhadap nilai-nilai agama akan melahirkan suatu sikap tertentu sebagai buah dari pengamalan agama. Sikap ini akan berkaitan dengan kerukunan. Atho Muzhar dalam sebuah artikel yang berjudul "Toleransi Kehidupan Beragama di Indonesia: Sebuah Tinjauan Teologis dan Sosiologis" menyatakan adanya empat sikap dari perilaku umat beragama. Keempat sikap itu adalah pertama, klaim kebenaran mutlak yang ekslusif. Bagi penganut agama tertentu ia akan mengatakan bahwa agama sayalah yang paling benar, agama lain salah dan harus dihapuskan. Kedua, sikap aghnosistisme. Sikap ini menyatakan bahwa agama adalah membuat repot. Pada tipe ini seseorang bisa rukun, tetapi bukan karena beragama. Bisa saja rukun, justeru karena tanpa adanya agama. Sikap ini tidak cocok dengan Negara Pancasila. Ketiga, sikap sinkretisme, yaitu satu sikap yang menggabungkan antar agama. Sikap ini pada dasarnya mendorong kepada kerukunan, tetapi salah dalam pelaksanannya. Karena sikap ini dapat mengambil percikan ajaran agama satu kemudian digabungkan dengan percikan agama satu lainnya. Keempat, sikap multikultularisme, yaitu suatu sikap dari paham bahwa agamanya sendiri adalah yang benar, tetapi pada waktu yang sama juga menghormati pemeluk ajaran agama lainnya (Maarif, 2009).

Dari keempat sikap tersebut yang paling menonjol untuk dikaji, setidaknya berkaitan dengan judul disertasi ini adalah sikap yang pertama dan keempat. Dengan sikap pertama seseorang berkecenderungan memiliki klaim kebenaran bagi agama tertentu yang dia anut. Karena dari sikap ini akan lahir sikap eklusif. Kedua adalah sikap multikulturalisme. Hal mana seseorang merasa bahwa agamanya sendiri adalah yang benar, tetapi pada saat yang sama juga dapat menghormati agama lain. Oleh karena itu pemerintah memberikan rambu-rambu bahwa meskipun agama yang dianut seseorang diyakini kebenarannya dan akan senantiasa disiarkan, tetapi dalam penyiarannya tetap dalam semangat kerukunan, tenggang rasa, teposeliro, saling menghargai, hormat menghormati antar umat beragama sesuai dengan Pancasila (Abdullah, 1994).

Dari sinilah berlaku kaidah lakum dinukum wa liyadin artinya: bagimu agamamu dan bagiku agamaku. Sehingga dengan demikian jelaslah kavling toleransi beragama, hal mana seseorang tidak boleh masuk wilayah prinsipil yaitu akidah dan amaliyah (Yusefri, 2017).

Salah satu dari cerminan khusu' dan tawadu' itu adalah penghormatannya terhadap penganut agama lain (Wahid, Paige, \& Rahman, 1998). Suatu perilaku yang memberikan pengertian bahwa risalah Islam berkasih sayang dengan umat manusia selain yang beragama Islam. Hal ini sebagaimana dilakukan oleh sayyidina 'Ali RA. Suatu ketika berangkat jama'ah untuk salat fajar. Bertemulah Ali dengan seorang yang sudah tua renta di tengah jalan. Kemudian Ali tidak mau mendahuluinya karena ingin memuliakan dan mengagungkannya sehingga matahari hampir terbit. Saat dekat dengan pintu masjid, orang tua tadi pun tidak masuk masjid karena beda agama (Nasrani). Kemudian Ali masuk masjid dan menemukan Rasulullah sedang ruku' shalat subuh. Ruku' Rasul tidak seperti biasanya, tetapi lebih lama sekira dua kali ruku', sehingga sayyidina Ali bisa mendapatkan ruku' bersamanya. Setelah selesai shalat, ditanyakan mengapa engkau ruku' demikian lama yang tidak seperti biasanya? Rasul menjawab saat Aku ruku' dan mengucapkan subhana rabbi al-azimi dan Aku hendak bangun datanglah malaikat Jibril menaruh sayapnya di atas punggungku serta memegangiku. Saat dia mengangkat sayapnya, maka bangunlah Aku. Para sahabat bertanya mengapa terjadi begini wahai Rasulullah? Rasul terdiam dan di jawab oleh malaikat Jibril bahwa sayyidina Ali itu pada dasarnya bersegera menuju ke 
masjid untuk jama'ah salat subuh, tetapi di jalan bertemu dengan orang tua dari Nasrani kemudian Ali memuliakannya. Allah SWT kemudian memerintahkan Aku untuk menahanmu bangun dari ruku', dan menyuruh malaikat Mikail untuk menahan matahari dengan sayapnya agar lamban terbit. Rasul kemudian bersabda inilah derajat dengan menghormati orang tua padahal ia adalah seorang Nasrani (al-Maqrizi, n.d.).

Riwayat di atas sejalan pula dengan hadis riwayat Bukhari dari Muhammad Ibnu Al-'Ala dari Mu'awiyah Ibnu Hisyam dari Syaiban, dari Faras dari 'Atiyah dari Abu Sa'id bahwa Nabi bersabda artinya: orang yang tidak berbelas kasih tidak diberi belas kasih". Juga riwayat Muhammad Ibnu Salam dari Jarir Ibnu Abdillah bahwa Rasul bersabda artinya: "Allah tidak akan mengasihi seseorang yang tidak mengasihi manusia lainnya" (Al-Bukhari, 2005).

Dalam ungkapan yang sederhana sebagaimana dikatakan Nur Syam yang dikutip Ismail Yahya, bahwa Islam rahmatan li al-'alamin adalah Islam yang mengembangkan pola hubungan antar manusia yang pluralis, humanis, dialogis dan toleran serta memperhatikan terhadap pengembangan dan pemanfaatan serta pengelolaan alam semesta dengan rasa kasih sayang. Pluralis memiliki relasi tanpa pandang suku, bangsa, agama, rasa ataupun yang membedakan antara satu orang dengan orang lain. Humanis dalam arti menjunjung tinggi hak asasi manusia dan menghargai manusia lainya sebagai manusia. Dialogis dalam arti semua persoalan didiskusikan dengan beragam pemikiran. Toleran dalam arti memberi kesempatan kepada yang lain untuk melakukan sebagai yang diyakininya dengan penuh rasa damai maupun relasi dengan alam (Yahya, 2019).

Islam rahmatan li al 'alamin, adalah fungsi Islam secara universal akan membebaskan pemeluknya dari kungkungan formalitas keagamaan yang sempit, sehingga dapat memperhatikan pada hal-hal yang lebih universal sehingga dapat lebih leluasa berpartisipasi dalam dunia yang lebih luas tanpa dibatasi budaya dan agama yang justeru dapat membelenggu diri sendiri, dengan melepaskan diri dari sekat-sekat tata cara peribadahan semata (Wulandari, 2020).

Dengan demikian meskipun beda agama tidak boleh merusak menghina peribadahan umat lain. Dalam surat al-An'am 108 Allah Berfirman artinya: “Dan janganlah kamu memaki sembahansembahan yang mereka sembah selain Allah, karena mereka nanti akan memaki Allah dengan melampaui batas tanpa pengetahuan. Demikianlah Kami jadikan setiap umat menganggap baik pekerjaan mereka. kemudian kepada Tuhan merekalah kembali mereka, lalu Dia memberitakan kepada mereka apa yang dahulu mereka kerjakan."

Melalui ayat di atas Allah SWT. melarang kepada utusannya dan juga orang-orang beriman pengikutnya dari menghina sesembahan orang-orang musyrik. Kecuali memang di dalamnya terdapat kerusakan yang besar. Yaitu perlawanan orang-orang musyrik dengan penghinaan terhadap sesembahan orang yang beriman yaitu Allah SWT. Dari sini pula menjadi terlarang untuk menghina sesama manusia. Dalam sebuah riwayat yang sahih Rasul bersabda: Terlaknat orang yang menghina kedua orang tuanya. Sahabat bertanya: bagaimana seorang laki-menghina kedua orang tuanya? Seseorang menghina ayah seorang laki-laki, maka ia pun akan membalasnya dengan menghina ayahnya. Ketika ia menghina ibunya, ia pun akan menghina ibunya juga (Syakir, 2005).

\section{Kerukunan Antar Umat Beragama dengan Pemerintah}

Dalam pidato pembukaan Musyawarah Antar Umat Beragama tanggal 30 November 1967 Menteri Agama K.H. M. Dahlan mengatakan bahwa kerukunan antara umat beragama adalah syarat mutlak bagi terwujudnya stabilitas politik dan ekonomi Negara. Menteri Agama berharap adanya kerjasama antara Pemerintah dan umat beragama untuk menciptakan iklim kerukunan beragama agar cita-cita bersama mewujudkan masyarakat adil dan makmur di bawah lindungan Tuhan Yang Maha Esa dapat terwujud (Abdullah, 1994).

Dalam surat An-Nisa ayat 59 Allah berfirman artinya: Hai orang-orang yang beriman, taatilah Allah dan taatilah Rasul (Nya), dan ulil amri di antara kamu. kemudian jika kamu berlainan Pendapat tentang sesuatu, Maka kembalikanlah ia kepada Allah (Al Quran) dan Rasul (sunnahnya), jika kamu benar-benar beriman kepada Allah dan hari kemudian. yang demikian itu lebih utama (bagimu) dan lebih baik akibatnya. 
Ibnu Abbas dalam menafsirkan kata ulil amri dengan ahli fikih dan agama. Demikian juga Mujahid, 'Ata, Hasan al-Bisri. Sedangkan Abu al-Aliyah dengan 'Ulama. Akan tetapi ahli Zahir menyatakan bahwa kedudukan ulil amri bersifat umum, baik kalangan umara' maupun ulama (Syakir, 2005).

Terlepas dari perbedaan kesan ulama terhadap kata ulil amri, dapat dikatakan bahwa dalam ayat di atas ketaatan kepada ulil amri disejajarkan dengan ketaatan kepada Allah dan ketaatan kepada rasul. Ketaatan terhadap pemerintah wajib hukumnya sejauh pemerintah tersebut tidak memerintahkan untuk berbuat maksiat. Ketaatan itu terbatas pada hal-hal yang sifatnya baik (makruf). Jika melalui tangan pemerintah untuk taat kepada Allah juga, bagi umat beragama tidak boleh mengelak. Karena pada hakikatnya tidak ada ketaatan bagi makhluk dalam maksiat kepada Allah SWT (Syakir, 2005).

Toleransi antar umat beragama harus diwujudkan pada tindakan-tindakan nyata yaitu saling menghargai, menghormati, menolong, mengasihi, tidak menghina ajaran agama lain serta memberi kesempatan pada pemeluk agama lain menjalankan ibadahnya (Suryan, 2017). Sikap toleransi sangat diperlukan dalam menciptakan kehidupan yang rukun dan damai dalam umat beragama karena pada dasarnya sikap toleransi dapat melatih dan membiasakan hati manusia untuk menjadi umat yang dapat memahami serta mengerti akan setiap kebutuhan dan kepentingan orang lain. Umat Bergama dan pemerintah harus melakukan upaya bersama dalam memelihara kerukunan umat beragama, dalam bidang pelayanan, pengaturan dan pemberdayaan (Lumowa, n.d.).

Berdirinya Negara Kesatuan Republik Indonesia adalah merupakan kesepakatan bersama antar umat beragama. Sehingga mengapa dalam sila pertama Pancasila dihilangkan tujuh kata, karena jika dipertahankan akan memberatkan umat lain. Karena merupakan kesepakatan bersama, maka kerukunan umat beragama adalah tanggung jawab bersama antar umat beragama dan pemerintah dalam rangka mewujudkan pembangunan nasional dan menjaga keutuhan Negara Kesatuan Republik Indonesia (Rusydi \& Zolehah, 2018).

Kerukunan umat beragama dengan pemerintah dapat dicontohkan misalnya saling menghargai dan menghormati keberadaan agama lain. Saling menghormati hari-hari besar masing-masing agama. Tidak saling mengejek antar umat beragama. Menghargai keputusan pemerintah tentang ditetapkannya peraturan bersama selama peraturan tersebut dan berakibat burut. Tidak saling membenci, berkiomentar buruk, atau menyebar virus kebencian melalui media sosial, seharusnya memberikan pesan damai dan toleransi antar umat beragama (Nazmudin, 2017).

\section{Kesimpulan}

Berdasarkan penelitian yang dilakukan dapat ditemukan beberapa hal-hal sebagai berikut: pertama, kata rahmat memilki beberapa arti yang secara umum dapat dikelompokkan dalam dua kelompok besar yaitu: a) Fisik/material dengan arti: hujan, surga, rezeki; dan b) Non Fisik/Immaterial seperti kosakata rahmat diartikan dengan: karunia, kebijaksanaan, wahyu, pahala, dan agama Islam. Kedua, dalam memahami kosa kata rahmatan li Al-Alamin dan perwujudannya dalam kehidupan nyata, para ulama dan para ahli agama di kalangan umat Islam terdapat dua pendapat yaitu: Kelompok Formalistik yang berpendapat bahwa agar rahmatan li al-'alamin dapat berguna nyata maka haruslah terlembaga dalam bentuk Negara. Sehingga menurut mereka pembentukan Negara Islam dalam bentuk Khilafah Islamiyah adalah mutlak adanya. Yang kedua adalah Kelompok Moralistik yaitu yang tidak mementingkan bentuk Negara, tetapi lebih menekankan ajaran agama khususnya Islam menjadi basis mental dalam kehidupan sehari-hari dalam berbagai sektor kehidupannya, baik ekonomi, sosial, politik maupun yang lainnya berlandaskan moral agama dengan berbasis pada rahmatan li al-'alamin. Sementara itu, perwujudan Rahmatan li Al-Alamin dapat terkendala dengan hal-hal seperti: berlebihan dalam masalah aqidah dan berlebihan dalam masalah percabangan agama (juz'iyyah).

\section{Referensi}

'Imarah, M. M. (n.d.). Jawahir Al-Bukhari. Al-Istiqamah.

Abdul Wahhab, S. M. bin. (n.d.). Al-Usul Al-Khamsah.

Abdullah, A. G. (1994). Pengantar Kompilasi Hukum Islam dalam Tata Hukum Indonesia. Gema Insani. 
Ad-Dardiri, A. A.-B. S. A. (n.d.). Qisah Al-Mi'raj. Maktabah Raja Murah.

al-Asqalani, A.-H. A. bin A. bin H. (n.d.). Bulug Al-Maram (Edisi Indo). Dar Assiddiq.

Al-Asqalani, A.-H. I. H. (2015). Bulughul Maram. Pustaka Al-Kautsar.

Al-Asqalanī, S. A. al-F., \& bin Hajar, A. bin'Alī. (n.d.). Fathu al-Bārī bisyarah Şahīh al-Bukhārī, juz XI. Beirut: Dār al-Ma'rifah.

al-Bajurî, I. (2007). Tahqiq al-Maqam ‘ala Kifâyah al-'Awam. Jilid II. Mesir: Dâr al-Taba 'ah al-Kubra al-Mishriyyah, 1280.

Al-Bantani, S. M. bin U. A.-N. (2002). Tanqih Al-Qaul Al-Hasis. Toha Putra.

Al-Bukhari, A. A. M. I. I. (2005). Al-Adab Al-Mufrad, Tahqiq Farid Abdul Aziz Al-Jundi. Dar Al-Hadis.

AL-GHAZALI, M. P. I. (n.d.). KONSEP HARTA DAN KESEJAHTERAAN.

Al-Hisni, T. A. B. I. M. A.-H. (n.d.). Ad-Dimasyqi Asy-Syafi'i Juz 1. Maktabah Al-Buhus Wa Ad-Dirasat Dar AlFikr.

Al-Jabbar, U. A. (n.d.). Mabadi' Al-Fiqhiyyah, Juz III. Maktabah Dar Al-Fatah.

Al-Jawi, A.-S. A.-I. A.-'Alim A.-F. M. N. (n.d.). Marqah Su'ud At-Tasdiq. Pustaka Al-Alawiyah.

Al-Jawi, A.-S. A.-I. A.-A. A.-F. M. N. (n.d.). Marqah Su'ud At-Tasdiq. Pustaka Al-Alawiyah.

Al-Jawi, M. N. I. U. (n.d.). Nasaih Al-'Tbad. Maktabah Keluarga.

Al-Jawi, S. N. (n.d.). As-Simar Al-Yaniyah Fi Riyad Al-Badi'ah. Maktabah Keluarga.

Al-Jaza'iri, A. B. J. (1976). Minhaj al-muslim. Alaf 21.

Al-Malaybary, Z. bin A. A. (n.d.). Fath Al-Mu'in. Maktabah Imaratillah.

al-Maqrizi, T. al-D. A. (n.d.). Kitab al-mawa 'iz wa'li 'tibar bi-dhikr al-khitat wa'l-athar. Bulaq, 1270, 1853-1854.

Al-Mas'udiy, H. H. (n.d.). Taysir Al-Khallaq. Maktabah Ahmad bin Sa'ad bin Nabhan wa auladuhu.

Al-Qur'an, L. P. M., \& Beragama, H. A.-U. (2014). Tafsir Al-Qur'an Tematik. Jakarta: Kamil Pustaka.

Albar, D., Rahman, M. T., SAM, M. N. B., Munawwaroh, S. M., Wasehudin, W., \& Budiana, Y. (2020). Penciptaan dan Pemeliharaan Alam dalam Perspektif Al-Qur'an. Prodi S2 Studi Agama-Agama UIN Sunan Gunung Djati Bandung.

Arifin, M. (2020). Apa arti Islam Rahmatan lil ‘alamin? Nikmat Islam. c om.

Chalim, A. (2018). Nilai-Nilai Pendidikan Toleransi Dalam Al-Qur'an Surah Yunus Ayat 40-41 Dan Al-Baqarah Ayat 256. IAIN SALATIGA.

Departemen Agama, B. P. K. R. R. K. W. (2004). Pendidikan Kesehatan Reproduksi Remaja. Semarang.

Departemen Agama, R. I. (2005). Al-quran dan Terjemahannya. In Semarang: Toha.

Djelantik, S. (2010). Terorisme: Tinjauan Psiko-Politis, Peran Media, Kemiskinan, dan Keamanan Nasional. Yayasan Pustaka Obor Indonesia.

Edyar, B. (2017). Religious Radicalism, Jihad And Terrorism. AJIS, 2(1).

Hamka, B. (1982). TAFSIR AL-AZHAR. Pustaka Panjimas.

Ibnu Ismail, A.-S. I. (n.d.). Ta'lim Al-Muta'allim. Maktabah Raja Murah.

Jabar, U. 'Abdul. (n.d.). Khulasoh Nur Al-Yaqin Fi Sirat Al-Khulafa' Ar-Rasyidin, Juz III. Maktabah Ahmad Bin Sa'd Bin Nabhan Wa Auladuh.

Kafid, N. (2016). Dari Islamisme ke "Premanisme": Pergeseran Orientasi Gerakan Kelompok Islam Radikal di Era Desentralisasi Demokrasi. MASYARAKAT: Jurnal Sosiologi, 57-79.

Kusen, K. (2017). Islamic Religious Learning In Providing Understanding Of Radical Hazards Based On Affection Approach (Study on Islamic religious Subjects at Junior High School). AJIS: Academic Journal of Islamic Studies, 2(1), 67-90.

Lambang, T. (2007). Pembangunan Sebagai Perdamaian. Yayasan Obor, Jakarta.

Lumowa, F. (n.d.). Media Online: Teknik Dasar Penulisan Berita. Arlikel dan Bahasa Jurnalislik, sulut. kemenag. go. idlfile/file/humas/zuvw, 1339679719.

Maarif, A. S. (2009). Islam dalam bingkai keindonesiaan dan kemanusiaan: sebuah refleksi sejarah. PT Mizan Publika.

Majah, S. I. (1952). Dar Ihya al Kutub al Arabiyah. Cairo.

Munandar, S. A. (2019). Islam Rahmatan Li Al-'Alamin Dalam Perspektif Nahdlatul Ulama. Jurnal Pendidikan Islam ELTarbawi, 11.

Mustafa, B. (n.d.). Rawihah Al-Aqwan. Menara Kudus.

Nasir, M. (2016). The Historical Background of The Ideology of Terrorism In Indonesia After September 11, 2001. AJIS: Academic Journal of Islamic Studies, 1(1), 43-58.

Nasution, H. (2002). Ensiklopedi Islam Indonesia. Djambatan.

Nasution, H. (2018). Teologi Islam, aliran-aliran klasik sedjara analisa dan perbandingan. UI Press,.

Nata, A. (2016). Islam Rahmatan lil Alamin Sebagai Model Pendidikan Islam Memasuki Asean Community. Makalah disampaikan pada acara "Kuliah Tamu" Jurusan Pendidikan Agama Islam Fakultas Ilmu Tarbiyah dan Keguruan UIN Maulana Malik Ibrahim Malang Senin, 7. 
Nazmudin, N. (2017). Kerukunan dan Toleransi Antar Umat Beragama dalam Membangun Keutuhan Negara Kesatuan Republik Indonesia (NKRI). Journal of Government and Civil Society, 1(1), 23-39.

Ni'mah, W. (2020). Islam Rahmatan Lil 'Alamin, Atau Lil Muslimin. Buletin Suara Mahad IAIN Walisongo. Pratama, A. N. (2018). Ini 30 Macam Hak Asasi Manusia Menurut PBB. Kompas.com.

Qattan, M. (2001). Tarikh at-Tasyri'al-Islami. Kairo: Maktabah Wahbah.

Qodir, Z. (2014). Radikalisme Agama di Indonesia: Pertautan Ideologi Politik Kontemporer dan Kekuasaan. Yogyakarta: Pustaka Pelajar.

Rida, M. (n.d.). Muhammad Rasulullah, Cet 4, Dar Ihya' Al-Kutub Al-'Arabiyyah. Isa Al-Babi Al-Halaby Wa Syurakauhu.

Rusydi, I., \& Zolehah, S. (2018). Makna Kerukunan Antar Umat Beragama Dalam Konteks Keislaman Dan Keindonesian. Al-Afkar, Journal For Islamic Studies, 1(1, January), 170-181.

Setiadi, E. M. (2017). Ilmu sosial $\mathcal{E}$ budaya dasar. Kencana.

Shihab, M. Q. (1996). Wawasan Al-Quran: Tafsir Tematik atas Pelbagai Persoalan Umat. Mizan Pustaka.

Shihab, M. Q. (2002). Tafsir al-misbah. Jakarta: lentera hati, 2.

Shihab, M. Q. (2007). “Membumikan” Al-Quran: fungsi dan peran wahyu dalam kehidupan masyarakat. Mizan Pustaka.

Shofaussamawati, S. (2017). Iman dan Kehidupan Sosial. Riwayah, 2(2), 211-224.

Sinaga, Y. H. (2020). Agama Islam Rahmatan Lil ‘Alamin. analisadaily.com.

Solihin, N. (2017). Understanding The Radicalism Movement In Indonesia: A Conflict Approach To The Rise Of Terrorism. AJIS, 2(1).

Sugiyarto, W. (2015). Profil Keagamaan Terpidana Terorisme di Indonesia. Jakarta: Kementerian Agama RI, Badan Litbang dan Diklat, Puslitbang Kehidupan Keagamaan.

Sulhan, M. (2018). Deradikalisasi Islam Indonesia: Studi pemikiran Islam Nahdlatul Ulama.

Suryan, S. (2017). Toleransi Antarumat Beragama: Perspektif Islam. Jurnal Ushuluddin, 23(2), 185-200.

Syakir, A. (2005). Umdah at Tafsir an al Hafidz Ibnu Kathir.

Syarqowi, A. R. (2003). Muhammad Sang Pembebas: Sebuah Novel Sejarah. Yogyakarta: Mitra Pustaka.

Syukron, B. (2017). Agama dalam pusaran konflik. Ri'ayah, 2(01).

Wahid, K. A., Paige, G., \& Rahman, M. T. (1998). Islam tanpa kekerasan. Yogyakarta: LKiS.

Wibisono, M. Y. (2020). Sosiologi Agama. Prodi P2 Studi Agama-Agama UIN Sunan Gunung Djati Bandung.

Wulandari, S. (2020). Islam Itu Rahmatan Lil ‘Alamin Bukan Rahmatan Lil Muslimin. Kompasiana.com.

Yahya, I. (2019). Islam Rahmatan Lil'alamin. diakses pada, 4.

Yusefri, Y. (2017). Syariat Islam Tentang Relasi dan Toleransi Antar Umat Beragama Dalam Alquran. Al-Istinbath: Jurnal Hukum Islam, 2(1), 47-74.

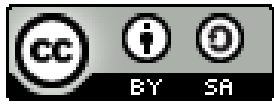

(C) 2021 by the author. Submitted for possible open access publication under the terms and conditions of the Creative Commons Attribution (CC BY SA) license (https://creativecommons.org/licenses/by-sa/3.0/). 